\title{
What if Europe Held an Election and No One Cared?
}

\author{
David Schleicher
}

TABle of Contents

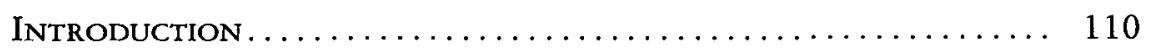

I. The Solutions and Problems of Assigning Power to a

Popularly Elected European Parliament........... 118

A. The European Parliament as a solution: bringing a popular voice on European issues into the separation of powers in the European Union....................... 119

B. European Parliament elections as a problem: European

Parliament elections track preferences about domestic policies

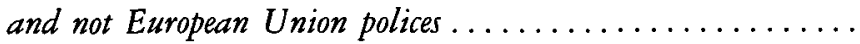

II. European Parliament Elections as an Institutional Problem: The Conflict between Reform and the Existing SEParation of Powers Inside the European UNION . . . . . . . . . . . . . . . . . . . . . . . . . . . . . 132

III. European Parliament Elections as a Mismatch

Problem: Using Election Law to Make the European

Parliament Play Its Institutional Role ............ 138

A. The problem of mismatch in European Parliament elections ... 139

1. A model of mismatch: why sub-national or supernational elections track national party preference ...... 139

2. Applying the mismatch model to European Parliament elections .......................... 144

B. An election law solution to the problem of mismatch in European Parliament elections.................. 148

1. Electoral engineering and institutional design ......... 149

2. Using distribution requirements to reduce the mismatch problem in European Parliament elections,.......... 152

IV. Conclusion: The Mismatch Problem in America and EUROPE 


\title{
What if Europe Held an Election and No One Cared?
}

\author{
David Schleicher*
}

\begin{abstract}
Last June's European Parliament ("EP") election was widely considered a failure. Turnout was low across Europe, and, as has been the case in every EP election since they were introduced in 1979, voters responded exclusively to domestic cues in deciding bow to fill the European Union's only directly elected body. Campaigns were waged entirely on domestic issues outside of the purview of the EP, and the popularity of domestic prime ministers, who were not on the ballot, was the most important factor in determining the results. The EP is supposed to provide a popular check on the otber legislative bodies in the European Union ("EU"), which are eitber appointed or directly controlled by member state governments, and thereby reduce the EU's "democratic deficit." Instead, the failure of EP elections to generate popular feedback on $E U$ policy allows the deficit to fester and undermines the separation of powers inside the $E U$.

This paper argues that the problems of EP elections are mucb like the problems in a variety of American state and local elections. Election laws ensure that national parties are on the ballot, and botb legal limitations and strategic considerations make it difficult for these national parties to develop separate localized identities, or in the case of EP elections, Europeanized ones. Rationally ignorant voters who know little about the individual figures in these European bodies rely on the party beuristic that is available on the ballot, as it is the only relevant information that they bave. Moreover, they do so even though it is unclear bow closely preferences on European or local policies track preferences about national issues. The result is that national party preference ends up being reflected in these elections, despite the fact that the winners will decide policies at another level of government. Put another way, there is a "mismatch" between the institutional role the EP is asked to play in the EU's separation of powers-the voice of European citizens about EU policies-and the level of party competition at which EP elections are contested.

Mismatch problems are endemic in federal systems and are generated by constitutional structures that ask more of voters than they are capable of providing. However, they can be solved or at least mitigated with election law tools. Following a procedure used in a variety of developing countries, the $E U$ could pass a law that the EP will only seat members from those parties that both won seats from a given $E U$ country and received a certain percentage of the vote in a quarter of $E U$ member states. This would force the coalitions formed in the EP-the so-called "Euro-parties"—onto EP ballots, as parties would need to contest elections across Europe. Voters thus would have access to a European rather than national heuristic on the EP ballot, which would better allow them to use these elections to express preferences about $E U$ policy.
\end{abstract}

\section{INTRODUCTION}

Elections were held for the European Parliament ("EP")—-the only directly elected body in the European Union ("EU")-_in June 2009, but you can forgive yourself if you missed them. Despite an unprecedented EU-

* Assistant Professor, George Mason University School of Law. I would like to thank Michelle Boardman, Chris Elmendorf, Heather Gerken, Samuel Issacharoff, Rachel Harmon, Daryl Levinson, Jeremy Rabkin, and the participants at the Virginia Junior Faculty Forum and the University of Texas Law School Faculty Colloquium for their comments and advice. Also, thanks are due to Jared Fleischer and Matt Kelly for research assistance. 
funded media campaign to spur turnout, substantial doubt surrounding the future of EU institutional reform, and an enormous economic downturn, European voters barely registered that this election was taking place. ${ }^{1}$ Turnout hit an all-time low, and the widespread lack of interest allowed parties from the nationalist, xenophobic, and just strange fringes of European politics to win seats. ${ }^{2}$ Furthermore, the actual behavior of the Members of European Parliament ("MEPs") had little to do with the results. Instead, as they have in every EP election since the first in 1979, voters responded exclusively to domestic cues, with the elections turning almost solely on the popularity of domestic prime ministers and parties. ${ }^{3}$ In most voters' eyes, June's EP elections did not play a role greater than a midterm public opinion poll about people not on the ballot, despite the fact that these elections determined the composition of an increasingly powerful body inside the EU.

It was not supposed to be like this.

In 1979, with great fanfare, European voters were granted the power to directly elect their representatives for the EP. ${ }^{4}$ In several successive treaties revising the institutional structure of the $\mathrm{EU}$ since then, the $\mathrm{EP}$ has been given new and stronger powers, making it a major player in the EU's legislative process and leaving it only slightly weaker than the Council of the European Union, the legislative body in which member states of the EU

1. See, e.g., Markéta Hulpachová, Voters Still Unclear on EU Issues, Prague Post, June 3, 2009, at 1 (describing election campaigns); Alain Lamassoure, Continuation of the European Adventure Relies on Ireland, IRISH Times, Dec. 10, 2008, at 18 (describing doubt about the future of EU reforms following Irish rejection of the Treaty of Lisbon); Martin Wolf, This Crisis is a Moment, but is it a Defining One?, Fin. Times, May 19, 2009, available at http://www.fullermoney.com/content/2009-05-20/FT_ThisCrisisIsA_ MomentButIsItADefiningOne20May09.pdf ("Europe . . . is not having a good crisis.").

2. Total turnout was forty-three percent, far lower than the turnout for domestic elections, and a number that overstates actual interest since it includes turnout numbers from countries where voring is mandatory. See, e.g., David Charter \& Rory Watson, European Elections: Extremist and Fringe Parties are the Big Winners, TIMEs (U.K.), June 8, 2009, available at http:/www.timesonline.co.uk/tol/news/politics/ elections/article6452090.ece (discussing turnout); Jonathan Eyal, EU Parliament on Fringe of Lanacy; Newly Elected Rightist and Extremist Parties Have Little Clout but Could Undermine Unity, STRAITs Times (Sing.), June 14, 2009 (describing success of xenophobic, nationalist, and odd parties like the Pirate Party of Sweden); Swing Low, Swing Right; The European Elections, Economist, June 13, 2009 (discussing turnout and results) (hereinafter Swing Low, Swing Right]; Trouble at the Polls; The Worrying European Elections, ECONOMIST, June 13, 2009 (highlighting the success of xenophobic, nationalist, and odd parties like the Pirate Party of Sweden).

3. A model created by three leading European political scientists using national party preferences as its central variable predicted ninety percent of the seats won in the 2009 elections. Simon Hix, Michael Marsh \& Nick Vivyan, Burson-Marsteller, Predict '09, June 8, 2009, http://www.webarchive.org.uk/ wayback/archive/20090609081906/predict09.eu/default/en-us.aspx. Following the first EP election in 1980, Karlheinz Reif and Hermann Schmitr first diagnosed EP elections as "second-order elections," or elections with results determined entirely by national party popularity. See Karlheinz Reif \& Hermann Schmitt, Nine Second-Order Nation Elections-A Conceptual Framework for the Analysis of European Election Results, 8 EUR. J. POl.. Research 3, 8 (1980). This result has held up in studies of each EP election since 1979. See Simon Hix, What's Wrong with the European Union \& How to Fix It 80-84 (2008) [hereinafter Hix, What's Wrong]; Michael Marsh, Testing the Second-Order Election Model After Four European Elections, 28 BrJT. J. POL. SCl. 591, 606-07 (1999).

4. See Simon Hix, Abdul G. Noury \& Gérard Roland, Democratic Polrtics in the European Parliament 13 (2007) [hereinafter Democratic Politics]. 
vote directly.5 The EP is now one of the world's most powerful directlyelected legislative bodies, having the power to reject, amend, and veto legislation that governs an economic area larger than the United States. ${ }^{6}$ This process continues; the newly-enacted Treaty of Lisbon further extended the EP's powers, making it a true legislative lower house-a House of Representatives to the Council's Senate. ${ }^{7}$

The reason why EU leaders have repeatedly increased the powers of the EP is clear. Giving power to a directly-elected body was considered a way to cure the "democratic deficit," or the perceived inability of European citizens to influence EU decisionmaking. ${ }^{8}$ The EP is supposed to provide a popular counterweight to both the member-state controlled Council and the powerful European Commission, an appointed body that is intentionally somewhat removed from popular and national political pressures and that serves primarily as the executive branch of the EU, while also exercising important legislative functions. ${ }^{9}$ Popular elections to an increasingly powerful EP were supposed to provide European voters a direct and important role in the EU's separation of powers. ${ }^{10}$

These direct elections, however, have never captured the attention of the European populace. Voter turnout in EP elections has fallen in each election since 1979 and is far lower than turnout in domestic elections. ${ }^{11}$ More pressingly, it has become what amounts to a social scientific fact that these elections are not responsive to anything actually done by the EP. Instead, EP

5. See infra notes $46-59$ and accompanying text.

6. See infra note 50 and accompanying text; see also Bruce Stokes, U.S. Economic Hegemony Ebbs, 40 Nat'L J. 17, 17 (2008) (noting that EU formed a larger single market than the United States).

7. See Treaty of Lisbon Amending the Treaty on European Union and the Treaty Establishing the European Community, Dec. 13, 2007, 2007, O.J. (C 306) 1 [hereinafter Treaty of Lisbon]; Dan Bilefsky \& Steven Castle, Way is Clear to Centralize Europe's Power, N.Y. Times, Nov. 3, 2009, at A6; Célia Sampol, Lisbon Treaty: Lisbon Will Strengthen Parliament's Powers, Europolitics (June 29, 2009), http://www. europolitics.info/lisbon-will-strengthen-parliament-s-powers-artr241 126-32.html. The analogy does not hold perfectly. First, member state governments vote directly in the Council, making state control over the Council far greater than U.S. state control over the Senate, even before the Seventeenth Amendment provided for direct elections. Second, voting is weighted by population in the Council, unlike the equal representation given to states in the U.S. Senate. See Ernest A. Young, Protecting Member State Autonomy in the European Union: Some Cautionary Tales from American Federalism, 77 N.Y.U. L. Rev. $1612,1626,1689$ (2002).

8. David Marquand coined the term "democratic deficit," arguing that an elected and powerful European Parliament would be necessary if the rule requiring unanimity among democratically responsive member states in the Council were removed (as it has been). David Marquand, Parliament for EUROPE 64-66 (1979). For a discussion of efforts to increase the power of the EP as a solution for the democratic deficit, see Peter L. Lindseth, Democratic Legitimacy and the Administrative Charater of Supranationalism: The Example of the European Community, 99 Colum. L. Rev. 628, 673-74 (1999).

9. See Young, supra note 7, at 1696-97. Members of the Commission are appointed by the Council, but the governing treaty of the EU is clear that the Commissioners should function independently and without influence from member states. Consolidated Version of the Treaty of the Functioning of the European Union arts. 244-45, May 9, 2008, 2008 O.J. (C 115) 47 [hereinafter TFEU].

10. See infra notes $60-65$ and accompanying text.

11. Mattias Kumm, To Be a European Citizen? The Absence of Constitutional Patriotism and the Constitutional Treaty, 11 Colum. J. Eur. L. 481, 512 (2005) (citing voter turnout figures in 2004 EP elections and comparing them to previous EP election turnout and domestic rurnout). 
elections are "second-order": national politics determine the results of these supra-national elections. ${ }^{12}$ As political scientist Simon Hix has noted, "The problem is that European Parliament elections actually have very little to do with 'Europe!' . . . Instead, voters, the media, and national parties treat European Parliament elections as just another set of domestic elections, where the dominant issue is how well national governments have performed." 13

Despite the absence of democratic pedigree or retrospective check on their behavior, something odd happens when MEPs arrive in Strasbourg. ${ }^{14}$ In elections for the EP, voters choose between domestic parties listed on the ballot-Labour, the Conservatives and the Liberal Democrats in Britain; the UMP and the Parti Socialiste in France. ${ }^{15}$ But once elected, MEPs join coalitions of likeminded national parties, forming supra-national parties such as the Party of European Socialists, comprised of the Labour party, the Parti Socialiste and other center-left parties across Europe. ${ }^{16}$ These "Euro-parties" are now legally separate entities, well-organized, and funded with EU grants. ${ }^{17}$ Their members are also quite unified on ideological groundsMEP voting patterns demonstrate tight party cohesion. ${ }^{18}$

As a result, the EP looks and sounds like a democratically elected legislature, with parties organizing votes, predictable ideological splits, lobbyists loitering in the hallways, and members making preening speeches. Yet, there is one missing element: any semblance of democratic control. Voters have no idea who the MEPs are, do not care about what they do, and certainly do nothing to punish their bad behavior. ${ }^{19}$ Voter disengagement from the EP has ensured that the decision to give it more power failed to confer much democratic legitimacy on the EU as a whole. In fact, polls reveal a collapse in popular support for the EU since granting the EP real power. ${ }^{20}$

12. See supra note 3 .

13. HIx, WHAT'S WRONG, supra note 3 , at 79.

14. Strasbourg, France is the official seat of the European Parliament, and where plenary sessions are held. Kristin Archick \& Derek E. Mix, Cong. Research Serv., RS 21998, The European Parliament 8 (2010).

15. The parties listed are only meant to be illustrative of the fact that domestic parties appear on the EP ballot. For a full list of parties and results in EP elections by country by year, see Europe PoLrTique (Oct. 3, 2010), http://www.europe-politique.eu/.

16. See Simon Hix \& Christopher Lord, Political Parties in the European Union $55-90$ (1997). For a full listing of how each domestic party in Europe relates to Euro-parties in the EP, see the European Parliament's European Election Results. Election Results: The New Parliament, European ParLIAMENT (July 16, 2009), http://www.europarl.europa.eu/parliament/archive/elections2009/en/ index_en.hrml.

17. See infra notes 107-110 and accompanying text.

18. See Democratic Politics, supra note 4, at 180-91.

19. See id. at 26-29; see also HIX \& LoRD, supra note 16, at 55-90.

20. Hix, What's WRONG, supra note 3 , at $52-53$ (noting the collapse in support for the EU from late 1980 s to mid 1990s); Democratic Poutics, supra note 4, at 14-15 (illustrating in Table 1.1 the EP's increase of power through the introduction of the cooperation procedure in 1987, the co-decision procedure in 1993, and the reform and extension of co-decision in 1999). 
With the ability to pass legislation that affects hundreds of millions of people in an increasing number of ways, the EP is now undoubtedly an important body - in last the last few years, they have passed legislation governing everything from carbon emissions to mobile telephony ${ }^{21}$-and it is therefore both surprising and problematic that voters cannot be bothered to form independent judgments about its policies. It is equally surprising that despite the flaws of its elections, European states continue to grant the EP more power in an effort to resolve the democratic deficit, like a nervous gambler doubling his bets after a series of losses. This Article will argue that EP elections fail to reflect voter preferences about EU issues because the laws governing these elections limit, or at least do not encourage, the development of pan-European party competition. Absent such competition, underinformed voters simply will not use these elections to serve the goals intended by the EU's institutional framers. Further, it will argue that using the tools of election law, European elections can be fixed such that the EP can play the role envisioned for it under the EU's current separation of powers.

Scholars who have studied the failures of EP elections have argued that the EU should change its broader institutional system. Some argue for replacing the current EU institutional framework with one in which European elections determine the makeup of all EU institutions, in an effort to make the elections important enough for voters to care about. Others argue that the failures of EP elections are not really a problem at all, claiming that the EU does not need much direct voter input. ${ }^{22}$ These arguments are interesting, but require radical departures from the current, carefully drawn separation of powers in the EU between directly-elected, member-state representing, and insulated bureaucratic bodies.

Instead of reforming its institutional structure, the EU should look at changes that can affect the elections themselves. Election law and constitutional law scholars have begun examining what I will call here "mismatch" problems in American elections, where the question an election asks of voters and the tools provided by the election law system are different. ${ }^{23}$ This is what occurs in EP elections-voters are asked their input on EU policies but see domestic parties on their ballots. Rather than focusing on changing the allocation of powers between the EP, the Council, and the Commission, or abandoning the idea that the EP should provide direct democratic feedback, European policymakers could attempt to solve the mismatch problem by manipulating the information on election ballots.

21. See infra note 50 and accompanying text.

22. See infra notes 123-137 and accompanying text. Simon Hix and Andrew Moravcsik, whose work is discussed below, do not actually call for treaty amendments, but rather for changes in institutional focus by widespread elite agreement.

23. See infra notes $224-237$ and accompanying text. 
It has long been known that most voters are under-informed about politics everywhere, and with good reason-any individual vote is not instrumentally important and the private benefits of casting an informed ballot are even less clear. ${ }^{24}$ The only mechanism that saves elections from utter incoherence is the political party. If parties stay roughly consistent in their policies over time, voters can develop "running tallies" of whatever retrospective evaluations they have of different policies practiced or promised by party members. ${ }^{25}$ If party names appear on the ballot, voters can tie these tallies to voting decisions, allowing even basically uninformed voters the opportunity to provide at least some meaningful feedback. The key, though, is for the party name to provide a clear and consistent heuristic, or informational shortcut, for voters. Accurate and consistent party labels reduce the cost of being informed by providing a link between observations and actual voting decisions, making it more likely that voters will cast informed ballots.

However, where vorers are provided with party heuristics on the ballot that do not match the level at which elections are being held, reliance on those party heuristics will not necessarily lead to informed decisionmaking. As noted above, voters in EP elections see only domestic parties (and a few fringe ones) on their ballot. Given how we believe voters develop and use political knowledge, it is unsurprising that they use them to comment on the performance of domestic parties-it is what is in front of them. The lack of labels on the ballot that refer to voting patterns and behavior in the EP makes it impossible for rationally ignorant voters to express preferences about EU policy. The lack of attention to European issues and interest among voters thus partially results from the lack of useful labels for organizing what information they do have.

What appears on an election ballot is not purely the result of competitive political forces-ballots are legal documents and their contents reflect public policy choices. The reason domestic parties are on the ballot as opposed to some other set of choices is that European countries use largely the same laws to govern EP elections as they do domestic ones. ${ }^{26}$ Domestic parties are

24. See Anthony Downs, An Economic Theory of Democracy, $207-59$ (1957); llya Somin, Knowledge About Ignorance: New Directions in the Study of Political Information, 18 Critical Rev. 255, 260 62 (2006).

25. The "running tally" model was developed by Morris Fiorina. MORRIS FIORINA, RetrospeCtive Voting In AMERICAN Elections 65-78, 193-200 (1981). This model, and other arguments that voters use parties as shortcuts for information, have been criticized for minimizing the importance of voter ignorance. They argue that retrospective voting models fail to acknowledge that voters credit politicians for policies or events beyond their control, often do not know which party is in power, and treat party affiliation more like an ethnic or religious affiliation than one based on issues. See infra notes 164 and accompanying rext. As a result, critics argue that shortcuts do not allow voters to behave as if they were informed. These criticisms, however, are aimed at the argument that with political parties providing heuristics, voter behavior approaches what it would be were voters fully informed. They do not suggest that, absent political parties providing relevant heuristics, anything approaching representation of popular opinions about policies is possible.

26. See infra notes $186-188$ and accompanying texc. 
advantaged by these laws and have huge institutional strengths that allow them to dominate national discussion and run candidates in EP elections. Given the greater relative importance of national elections to these parties, however, they have little incentive to develop separate identities for the purposes of EP elections. Doing so would be risky to the stability of party coalitions and would not permit them to claim a domestic victory following success in EP elections.

Thus, part of the problem with EP elections is the way information is presented to under-informed voters. With just national political parties on the ballot, the information that these voters are given results in voting decisions based on issues (i.e. national politics) that are different from those that the EU framers wanted and expected voters to use (i.e. the actual decisions made by the EP). This does not have to be the case: The EU could change its election laws so that the heuristics provided to voters on the ballot correlate to the behavior of EP politicians. Just as relevant party labels make relevant the policy observations of relatively under-informed voters in other types of elections, election laws that spur the development of useful party information would serve to make for an electorate that is more informed and more capable of playing its intended role in the EU's institutional structure.

Specifically, the EU could adopt a system similar to the one used in Nigerian, Indonesian and Kenyan elections, which requires candidates to receive a certain percentage of the vote in a number of states as well as winning a certain share of the overall vote before receiving representation. EP elections use proportional representation, and under the laws of most member states, a party has to receive more than a threshold amount-usually five percent-in any given member state in order to have members elected to the EP from that country. ${ }^{27}$ Under this proposal, there would be a double threshold. In order for a party to get an MEP elected from any member state, the party would have to: (1) receive a certain percentage in the member state; and (2) receive a certain percentage in a set number of other EU member states. For instance, in order to receive representation in the French delegation to the EP, a party would have to receive, say, five percent of the French vote, and three percent of the vote in at least seven other EU member states. ${ }^{28}$

This rule would force parties to appear on the ballor under the same name in many countries. The likely result would be that the coalitions in the EP to which these parties belong - the Euro-parties - would be chosen to appear on the ballot in each country. ${ }^{29}$ French voters would see on their EP

27. See infra notes $211-213$ and accompanying text

28. The numbers here are not chosen at random-they directly mirror the standards that Euro-parties have to meet to receive funding from the EU. See infra note 209 and accompanying text.

29. That these parties already exist, with legal identities, funding sources, and staff, should reduce the difficulties of establishing new international organizations. See infra note 109 and accompanying text. Nothing about a distribution requirement actually necessitates substantive changes in the organization of 
ballots the Party of European Socialists and the European People's Party instead of the Parti Socialiste and the UMP. Voters would thus have a ballot notation that permits them to link observations of the behavior of MEPs to voting decisions in a low cost way. To the extent that voters notice decisions made by this increasingly powerful body, this would allow them to develop running tallies that would translate those observations into informed votes.

Importantly, this proposal only seeks to change EP elections to help the EP serve its institutional function. It is not an effort to engage in a broader reform of the EU. The proposed rule would not affect the power of the EU vis-à-vis the member states. It would have no effect on member state domestic elections and hence would not change the politics of the Council or the Commission. It would not even necessarily reduce the influence of domestic parties over the Euro-parties, which could still be governed by whatever internal rules they saw fit. All it would change is the notation on EP ballots. However, this minor change would give voters a better idea of the policies for which they are voting, changing the competitive dynamics of EP elections. Further, it would allow the Euro-party brands to develop identities separate from those of their domestic partners. By giving voters better information, this change would create a way for EP elections to be about the EU, allowing the EP to play its intended role in the EU's institutional system.

Now, it is quite possible that this would not work entirely as intended. Voters may still use domestic party support as their sole criterion for their vote even after the rule is enacted. This would still be the case, for example, if it turns out that voters cannot keep two separate party systems in their head at the same time. ${ }^{30}$ However, even if this reform proposal does not work as intended, it would be an improvement over the status quo. At the very least, it would limit the ability of candidates to make purely nationalistic appeals that would be unpopular in other countries, as candidates from a Euro-party in one country could be held accountable for statements of their co-partisans in another country. Further, it would provide some useful information to voters. These effects would be beneficial, even if the proposed reform did not completely resolve the problem of voter information in EP elections.

Of course, properly understanding what is wrong with the EP is itself important, but the claims in this Article have a broader reach. The problems of EP elections are basically the same as the problems in a variety of American local and state elections. Voters in these elections use their national

the national political parties that join together to form the Euro-parties. Parties would only need to change the label that appears on the ballot.

30. F. Scort Fitzgerald famously noted that "the test of a first-rate intelligence is the ability to hold two opposed ideas in the mind at the same time, and still retain the ability to function." F. Scort FitzGerald, The CRACK-Up (1936), available at http://www.esquire.com/features/the-crack-up. It is thus a real question whether an ordinary electorate could hold two separate, but not opposed ideas about two separate sets of political parties. For some evidence that voters in one place can develop preferences in two different party systems, see infra notes 219-221 and accompanying text. 
party preferences to determine their vote, even when those preferences only weakly correspond to policy preferences at the state or local level. ${ }^{31}$ They do so because of their general lack of information about politics and the way that ballots provide information. These "mismatch" problems are endemic in federal systems, and thinking about them systematically will be a boon to future constitutional framers. Understanding the range of possible responses-election law changes like the ones suggested here are far from the only option-will provide a toolbox for solving these problems when they do arise.

Finally, looking at mismatch problems has important implications for election law scholarship. While election law scholars have studied virtually every aspect of ballot access rules, laws governing political party members, and methods of vote counting, one effect of election law has largely been ignored: the degree to which election law serves to educate a poorly informed populace. ${ }^{32}$ The political science scholarship on how voters form political opinions shows that the subjects of election law (for example, who gets on the ballot, how internally consistent political parties are, etc.) are central to how voters process political information and how voting decisions are made. ${ }^{33}$ In addition to its other roles, election law serves as a public good, providing tools to voters that improve social welfare, which are not provided for by naturally occurring political markets. ${ }^{34}$ This Article suggests how these public goods can be delivered in a better way. In order to understand the full ramifications of virtually any election law decision, however, scholars need to consider the effects it has on the information easily accessible to voters.

\section{The Solutions and Problems of Assigning Power to a Popularly Elected European Parliament}

This section will provide a brief history of the EP, how European leaders envisioned it would work, and the evolution of EP elections. It will establish that problems with EP elections have frustrated the institutional goals behind the repeated decisions to increase the power of the EP over the last thirty years.

31. See David Schleicher, Why Is There No Partisan Competition in City Council Elections? The Role of Election Law, 23 J. L. \& PoL. 419, $437-47$ (2007) thereinafter Schleicher, City Council Elections]; see also infra notes 224-232.

32. For two excellent reviews of the modern field of election law, see Guy-Uriel E. Charles, Democracy and Distortion, 92 CoRNeu L. Rev. 601 (2007), and Guy-Uriel E. Charles, Judging the Law of Politics, 103 Mich. L. Rev. 1099, 1131-40 (2005).

33. See infra notes $157-158$ and accompanying text.

34. See infra notes $238-241$ and accompanying text. 


\section{A. The European Parliament as a solution: bringing a popular voice on European issues into the separation of powers in the European Union}

The current EU institutions did not spring fully formed, Athena-like, from the foreheads of Europe's post-war leaders. Rather, they developed over time in a series of treaties created to enhance the EU's capacity, to further European integration, and to solve the many problems inherent in building an institution that is unique in the world-somewhat more than an international organization but less than a state. ${ }^{35}$ The history of the EU's development is an oft-told tale, and I will not repeat that story here. However, it is important to provide a brief history of one of its core institutions: the European Parliament.

At the establishment of the European Economic Community (the precursor to the EU) in 1957, legislative and executive power was divided between two entities. ${ }^{36}$ The first was the European Commission, a multinational body with the power to propose legislation and regulations, with membership selected and provided by each of the member states, and with a Chair or President selected by European heads of state. ${ }^{37}$ The Commission, effectively a collection of top technocrats and senior politicians, served as the executive body of the EU, responsible for all regulations and administration. ${ }^{38}$ The other important entity was the European Council, in which each member state was represented. ${ }^{39}$ The Council approved legislation and major policies. ${ }^{40}$ There was also an odd entity created known as the European Parliament (although it was not formally given this name until 1985).41 Although the Treaty of Rome (the document that established the European Economic Community's institutional structure) assumed that this body would eventually be directly elected, it was not at first. Instead, it was composed of delegates from national parliaments. ${ }^{42}$ It had only two limited powers-the right to be consulted about legislation pending before the Commission and

35. For an abbreviated history of this lurching development, see Damian Chalmers et al., EuropeAN UNION LAW: Text and Materials 8-43 (2006).

36. See Hon. John P. Flaherty \& Maureen E. Lally-Green, The European Union: Where is it Now, 34 DuQ. L. Rev. 923, 933-36 (1996) (describing the power and make-up of the institutions of the EEC from 1958-1985).

37. Id. at 933 . It should be noted that the Commission did not take its full form until 1967, although it existed in large part following the Treaty of Rome. See Nicholas P. Zalany, The European Union Constitution and its Effects on Federalism in the EU, 66 OH1O ST. L.J. 615, 620 (2005).

38. See Young, supra note 7, at 1628.

39. See Flaherty \& Lally-Green, supra note 36 , at $941-42$. It is a distinct body from the Council of Europe, an entity in which heads of state from Europe meet to chart the long-run goals of the EU. Id.

40. The Council voted by unanimity at the outset, but since the Single European Treaty of 1986, it has used "qualified-majority voting" on some issues, where larger states are given more votes and there is a need to get supermajorities across more than one dimension. Simon Hix, The Poutical System of the European Union 83-89 (2d ed. 2005) [hereinafter The Political System]. The Council also has quasi-executive functions that fall somewhere between legislative monitoring of the executive and actual implementation of legislation. Id. at 35-38, 52-58.

41. See Democratic Politics, supra note 4, at 12.

42. Treaty Establishing the European Economic Community art. 138(3), Mar. 25, 1957, 298 U.N.T.S. 11; see also Flaherty \& Lally-Green, supra note 36 , at $941-42$. 
the right to censure the Commission by a double majority vote (a majority of all members of parliament as well as two thirds of those voting). ${ }^{43}$

From 1958 through 1979, the EP's power slowly increased, notably gaining the ability to amend the EU's budget in certain ways. ${ }^{44}$ In 1979 , however, the EP was dramatically reformed by the institution of direct elections. ${ }^{45}$ Successive treaties following 1979 increased the power of the EP in order to match the institutional legitimacy that came with its status as the only directly elected body in the EU. This power has come in two forms: legislative responsibility and control over the executive branch, the European Commission.

The EP was first given substantial legislative responsibility in the late 1980s. In the 1987 Single European Act, it gained the power to propose amendments and to delay the passage of legislation through the so-called "co-operation procedure." 46 True legislative power arrived in 1993, when the Maastricht Treaty assigned to the EP the power of "co-decision." $47 \mathrm{Al}$ though the Commission still has the exclusive right to propose new legislation, legislation in policy areas covered by co-decision (originally a limited swath of the EU's overall portfolio) must be approved by the EP as well as by the Council. ${ }^{48}$ When there are disagreements between the Council and the EP, an ad hoc conciliation committee is formed, consisting of an equal number of representatives from both bodies. The differences are then hashed out, similar to the operation of conference committees in the U.S. Congress. Both bodies must pass the final legislation. That is to say, Maastricht, and subsequent changes made in the 1999 Amsterdam Treaty, transformed the EP into a body comparable to a lower legislative house. ${ }^{49}$

43. See Democratic Politics, supra note 4, at 14.

44. Id.

45. See Flaherty \& Lally-Green, supra note 36 , at $941-42$.

46. Single European Act art. 149(2), Nov. 10, 1987, 1987 O.J. (L 169) 1 [hereinafter Single European Act]. This gave the Parliament the power to propose amendments and to delay the passage of legislation. See Democratic Politics, supra note 4, at 14, 19; Lindseth, supra note 8, at 673.

47. Treaty on European Union art. 189(b), Feb. 7, 1992, O.J. (C 191). In areas covered by co-decision, all legislation must be approved by the EP as well as by the Council. See Michael H. Abbey \& Nicholas Bromfield, A Practitioner's Guide to the Maastricht Treaty, 15 MiCH. J. INT'L L. 1329, 1350-51 (1994); Note, Environmental Effects of Codecision Under the Maastricht Treaty, 21 B.C. INT'L \& COMP. L. Rev. 247, 252-54 (1999) [hereinafter Environmental Effects].

48. See Abbey \& Bromfield, supra note 47, at 1350-51; Environmental Effects, supra note 47, at 247, 252-54.

49. Under the Maastricht Treaty, the bodies were not true equals even in those areas covered by codecision. Where the EP and Council could not agree, the Council was empowered to propose a version of legislation that could not be amended by the EP-it had to vote up or down. Because the EP tended to vote yes on legislation when given this "take it or leave it" choice, its power to truly effect legislation was limited. Some argued that introducing co-decision without the power to propose amendments actually weakened the EP. See, e.g., George Tsebelis, Maastricht and the Democratic Deficit, in Decision Rules in the European Union: A Rational Choice Perspective 16, 17 (P. Moser, G. Schneider \& G. Kirchgaessner eds., 2000). However, in 1999, following a decision by the EP to vote no on a Councilproposed piece of legislation on voice telephony, the Amsterdam Treaty removed this structural advantage for the Council. "The Parliament is now a powerful legislator, coequal with the Council under the 
These changes turned the EP into a central player in the EU's legislative process. In the last EP term (2004-2009), it was particularly active in single-market and environmental legislation-both of which effectively regulate all European businesses-rendering it one of the world's most powerful economic regulators. ${ }^{50}$ From the regulation of all service providers in the EU to an expansion of a cap-and-trade carbon emissions system, the EP has played a major role in determining how liberal, how harmonized, and how green European policy is.

The EP has also made its presence felt through its power to reject appointments to the European Commission. The Council nominates the President of the Commission, who, in consultation with member states, selects the rest of the Commission and assigns each Commissioner her portfolio in the Commission's cabinet-like system. ${ }^{\text {sl }}$ The Maastricht Treaty expanded the EP's control over the selection of the Commission, effectively granting it the power to vote up or down the appointment of the Commission President (a power formalized in 1999)..$^{52}$ The EP also retained a power it had held since the outset of the EU: the ability to censure or effectively remove the Commission by double majority vote. ${ }^{53}$ In 1990 , the threat of censure succeeded in provoking the resignation of the Jacques Santer-led Commission, following an EP report alleging corruption and nepotism. ${ }^{54}$ The full realization of the EP's power over the Commission, however, was not felt until 2004, when it initially vetoed the newly-appointed Commission and forced the resignation of Justice and Civil Liberties Commissioner Rocco Buttiglione, a conservative Italian politician who declared that homosexuality was a sin. ${ }^{55}$ The EP now has substantial control over the appointment of the President of the Commission, the choice of Commissioners, and the ability to remove the Commission in the case of misconduct.

The proposed EU Constitution would have made the Parliament even more powerful, expanding co-decision to all policy areas and granting the EP greater control over the EU budget. ${ }^{56}$ Although the Constitution was rejected by voters in several European countries, the substantive changes it

reformed codecision procedure." George Tsebelis \& Geoffrey Garrett, The Institutional Foundations of Intergovernmentalism and Supranationalism in the European Union, 55 INT'L ORG. 357, 359 (2001).

50. See At a Glance: Key EU Laws, BBC News (May 12, 2009, 12:04 GMT), http://news.bbc.co.uk/2/ hi/europe/7959853.stm

51. See The Political. System, supra note 40, at 41-43, 59-60. Until 1994, member states nominated the President of the Commission by unanimity, but the Council has done so by qualified majority votes since 1993. Id. at 59, 61 .

52. See Chalmers et al., supta note 35, at 116-17; Democratic Politics, supra note 4, at 14; The PotrTical System, supra note 40, at 59-60.

53. See Democratic Politics, supra note 4 , at $13-17$.

54. See The Political System, supra note 40, at 60-61.

55. See David Gow, Grateful Barroso Offers MEPs a Say on EU Reform, GunRdian (UK), Nov.19, 2004, at 21 ; see also Democratic Polrtics, supra note 4, at 1-3.

56. Treaty Establishing a Constitution for Europe art. I-19-20, Dec. 16, 2004, O.J. (C 310) [hereinafter Establishing Treaty]; see also Stephen C. Sieberson, The Proposed E.U. Constitution-Will it Eliminate the EU's Democratic Deficit?, 10 Colum. J. Eur. L. 173, 208-09 (2004). 
proposed to the EP's power (like much of the rest of the Constitution) were included in the Reform Treaty, or the Treaty of Lisbon. ${ }^{57}$ After Irish voters agreed to the Treaty in the second referendum on the subject (they rejected it the first time it was up for consideration), it was ratified by all European states in November 2009.58 The Reform Treaty expanded the EP's control over the EU budget, rebranded the co-decision process as the "ordinary legislative procedure," and expanded co-decision to cover agriculture and virtually all other areas of EU policy competence. ${ }^{59}$ This too brief history should make two things clear: first, that the EP's power has repeatedly increased between 1979 and 2009; and second, that the EP is now a very important institution, with direct control over legislation affecting hundreds of millions of people and billions of dollars of business and, through its power over nominations to the Commission, influence over all aspects of EU policy.

There is little question why the power and influence of the EP has been increased. As the EU developed, it gradually took responsibility over an increasing number of areas from member-state governments. Furthermore, successive treaties limited the ability of the democratically elected governments of member states to veto legislative action in the Council, as it moved in the majority of policy areas from a unanimity voting rule to "Qualified Majority Voting," a system in which a super-majority of votes is needed and the weight of each country's vote is determined by its population. ${ }^{60}$ In response, some politicians and scholars have developed a clear and deadly critique of its institutional apparatus: the EU was making policy that affected people's lives with little direct democratic input. ${ }^{61}$ In David Marquand's classic term, the EU suffered from a "democratic deficit"-it was increasingly powerful, but its legitimacy was undercut by how removed its decisions were from the people of Europe. ${ }^{62}$ While the Commission served as a bureaucratic enforcer of common European interests and the Council served to protect the interests of member states, there was no tribune through which the voice of the people could be heard directly.

Giving power to the Parliament has been the EU's regular response to arguments that it has become too bureaucratic, too decentralized, or insuffi-

57. Treaty of Lisbon, supra note 7; see also Bilefsky \& Castle, supra note 7; Youri Devuyst, The European Union's Institutional Balance After the Treaty of Lisbon: "Community Method" and "Democratic Deficit" Reassessed, 39 GEO. J. INT'L L. 247, $306-09$ (2008) (describing power of EP after Treaty of Lisbon); Valery Giscard D'Estaing, The Treaty is the Same as the Constitution, IndePEndent (U.K.), Oct. 30, 2007, available at http://www.independent.co.uk/opinion/commentators/valeacutery-giscard-destaing-che-eu-treaty-isthe-same-as-the-constitution-398286.html.

58. QEA: The Lisbon Treaty, BBC News (Feb. 5, 2010, 16:47 GMT), http://news.bbc.co.uk/2hi/ europe/6901353.stm.

59. Treaty of Lisbon, supra note 7 (showing that changes made are spread across many articles); see also Devuyst, supra note 57, at 306-09.

60. See HIX, WhAT's WRONG, supra note 3, at 4, 19 ("[Qualified Majority Voting] in the Council now covers all the main areas relating to the creation and reform of the internal marker"); see also THE Political SYSTEM, supra note 40, at 67-89.

61. Lindseth, supra note 8, at 673-74.

62. Marquand, supra note 8 , at 64-65. 
ciently democratic. ${ }^{63}$ However, it is important to note that giving power to the EP was supposed to be an incremental change. The EP is an additional check in the EU's complex system of checks and balances, a counterweight to the technocratic impulses of the Commission and the centripetal nature of the Council. In 1978, a key EP official described the role European leaders had envisioned for the Parliament after direct elections:

With the Commission representing the Community interest, and the Council the national interests, it is just as well that the Parliament exists as a balancing element ... the elected Parliament will receive its mandate directly from the peoples of the Community. It will be independent and autonomous with respect both to governments and states, deriving its legitimacy from the popular vote. ${ }^{64}$

Although the EP was just one piece of the broader EU puzzle, it was seen as an increasingly important one, as the EU's ever-expanding reach into new policy areas generated extreme pressure for it to resolve the "democratic deficit." 65 The EU's current institutional structure is premised on the theory that the EP will serve as a popular counterweight to the bureaucratic Commission and the member-state run Council. Further, the member states and European leaders generally have considered enhancing the EP's role as a necessary component of enhancing the EU's legitimacy, based on the theory that giving more power to a directly-elected body will reduce the "democratic deficit." Both of these, however, are just theories. And, as will be discussed in the next section, there are reasons to doubt that either is true.

\section{B. European Parliament elections as a problem: European Parliament elections track preferences about domestic policies and not European Union polices}

As discussed in the previous section, what makes the EP different from other EU institutions is the fact that its members are directly elected, and it is this fact that has spurred EU leaders to assign the EP more and more power over the last thirty years. As a directly elected body, the EP is supposed to provide a perspective on EU policy different from those offered by the bureaucratic Commission and the member-state run Council. Thus, the

63. See Young, supra note 7, at 1697 ("The primary response to concerns about a 'democratic deficit' has been a call to enhance the role of the European Parliament-the only directly elected institution in the Community system.").

64. Jean-Joseph Schwed, The Parliament and the Commission, 440 Annals AM. ACad. Pol. \& Soc. ScI. 33,34 (1978).

65. "The official strategy here has centered on a further increase in the role of the Community's elected body, the European Parliament-in effect, to make it the legitimate political superior in the community system. According to the European Court of Justice, the growing importance of the Parliament is an expression of 'the fundamental democratic principle that the people should take part in the exercise of power through the intermediary of a representative assembly." Lindseth, supra note 8, at 673 (quoting Case 138/79, SA Roquette Freres v. Council, 1980 E.C.R. 3333, 3360 I 33). 
success of the EP in fulfilling its institutional role turns on the quality and type of elections.

When elections for the EP were first announced in 1979, European leaders either expected or hoped that mass pan-European political parties would develop and push integration along, a popular political response to the fact that power had shifted from member states to the EU. ${ }^{66}$ This sentiment has become part of the EU's central document. The Treaty on the European Union states: "Political parties at European level contribute to forming European political awareness and to expressing the will of citizens of the Union."67 Pan-European parties were seen as an inevitable reaction to the establishment of a pan-European legislature, and their development would be key to its success.

Suffice to say, this did not come to pass. The major domestic parties in each country dominated elections in 1979, and have done so in every election since. ${ }^{68}$ Only the Green Party has ever won a seat in more than one country, and it is debatable whether to classify it as a pan-European party or a collection of related domestic parties. ${ }^{69}$ Other parties that have attempted a pan-European presence have failed to win substantial support. For instance, in the 2009 election, anti-European leader Declan Ganley, the billionaire who successfully led the "No" campaign against the first Treaty of Lisbon referendum in Ireland, founded a new political party, Libertas, that ran candidates for the EP across Europe. ${ }^{70}$ Nevertheless, Libertas only won one seat throughout the EU, and Ganley went down to defeat in Ireland. Furthermore, major domestic parties largely contest these elections in their own names, with no reference to their Euro-party affiliations. ${ }^{71}$

66. See Hix \& LoRd, supra note 16, at 12-16; Democratic Politics, supra note 4, at 51; David Marquand, Towards a Europe of the Parties, 49 Pol. Q. 425, 445 (1978) (arguing Europe could only move beyond its present as a "Europe des patries," in Charles de Gaulle's famous formulation, if it become a "Europe des partis.").

67. Stephen Day \& Jo Shaw, Developing Political Parties in the European Union: Towards a European Party Statute?, in Party Funding and Campaign Financing in International Perspective 293 (K.D. Ewing \& Samuel Issacharoff eds., 1993).

68. See Democratic Politics, supra note 4 , at 51.

69. In 2004, a variery of disparate national Green parties formed the European Green Party. They did so to contest the 2004 European Parliament elections with a common platform. See Peter Ford, Greens Seek Pan-European Political Clout, Christian Sci. Monitor, Mar. 1, 2004, at 6; History, The Greens I European Free Aluance in the European Parliament, http://www.greens-efa.org/cms/default/ rubrik/6/6648.history.htm (last visited Oct. 2, 2010).

70. See Swing Low, Swing Right, supra note 2.

71. See Hix \& LoRD, supra note 16 , at 15 ("national parties . . monopolise the mass political arena . . . .); Michael Marsh \& Mark Franklin, The Foundations: Unanswered Questions from the Study of European Elections, 1979-1994, in Choosing Europe? The European Electorate and National Politics in THE FACE Of Union 20 (Cees van der Eijk \& Mark Franklin eds., 1996). There are a few exceptions to this-for instance, the Irish party Fine Gael has used its membership in the European People's Party in its campaign literature. Marsh \& Franklin, supra, at 20. 
Candidates for the EP range from non-descript party politicians to notable national celebrities, but are usually not major politicians. ${ }^{72}$ Under EU law, member states must now use proportional representation or a single transferable vote system to fill their EP seats. ${ }^{73}$ Domestic parties choose the list of candidates, and their selections are often criticized for being based more on the desire to give sinecures to faithful party supporters and expoliticians than on any plan to choose popular candidates who can lead campaigns. ${ }^{74}$ When well-known politicians run for EP seats, it is usually because they have become political liabilities in domestic politics. For example, Rachinda Dati, a former Justice Minister in France, ran to become an MEP in 2009 after a rocky period in the French government. ${ }^{75}$ Moreover, when candidates are well-known, it is often not for their political successes. Candidate lists for the EP frequently feature celebrities. In 2009, candidates included a Prince from the House of Savoy, Lithuania's leading talk show host, a Finish rally car driver, and "Romania's Paris Hilton." 76 This trend reached its apex in Italy, when Silvio Berlusconi selected a group of female celebrities with no political experience-including a former reality television star, a soap opera actress, and a beauty pageant winner-to run as EP candidates for his People of Liberty Party, withdrawing his support only after his wife called the candidates "shameless rubbish" chosen solely for their looks. ${ }^{77}$

Despite the inclusion of these celebrities, turnout in EP elections is continuously relatively low. ${ }^{78}$ After the first EP election in 1979, when sixty-

72. See An Unloved Parliament, Economist, May 9, 2009, at 56 ("Leaders decry the practice of packing the European Parliament with failed politicians and cronies"); Shaken in Strasbourg, ECONOMIST, January 16,1999 , at 18 .

73. Council Decision of 25 June and 23 September 2002, 2002/772/EC, Amending the Act Concerning the Election of the Representatives of the European Parliament by Direct Universal Suffrage, Annexed to Decision 76/787/ECSC, EEC, Euratom, 2002 O.J. (L 283) 1 [hereinafter Euratom Treaty].

74. See Simon Hix, Parliamentary Behavior with Two Principals: Preferences, Parties, and Voting in the European Parliament, 46 AM. J. Pol. Scr. 688, 691 (2002) (national parties choose candidate lists); Charlemagne, Record Abstention in Euro-elections, Economist Charlemagne's Notebook, June 8 , 2009, 0:21), http://www.economist.com/blogs/charlemagne/2009/06/record_abstention_in_euroelect. cfm; An Unloved Parliament, supra note 72, at 18 ("Leaders decry the practice of packing the European Parliament with failed politicians and cronies.").

75. Matthew Saltmarch, What Next for a French Meteor?, INT'L Herald Trib., June 11, 2009, available at http://www.nytimes.com/2009/06/11/world/europe/1 1 ihtdati.html?_r $=1 \& s c p=1 \& s q=\% 22$ Whar $\%$ 20next\%20for\%20a\%20French\%20meteor\%22\&st=cse; See An Unloved Parliament, supra note 72, at 18. A similar story can be told about former French Prime Minister Michael Rocard. See Sarkozy's Moment: France's Reshuffled Government, Economist, Apr. 3, 2004 (noting that Rocard was dismissed as Prime Minister due to his unpopularity); Jeffrey Ulbrich, Wasbed-Up Windbags, Hobart Mercury (Austl.), Apr. 22, 1996 (noting that Rocard was only one among many "big names and fading stars" in the EP).

76. Paolo Tocaro, Struggling for Poll Position, SYDNEY MORNING Herald, June 5, 2009, available at http://www.smh.com.au/world/struggling-for-poll-position-20090604-bx9e.html.

77. Richard Owen, Silvio Berlusconi Makes Beauty Contest of European Poll, Australian, Apr. 24, 2009, available at http://www.theaustralian.com.au/news/silvio-makes-poll-beauty-contest/story-e6frg6to-1225 702973337; Peter Popham, The Last Days of the Court of King Silvio, IndePEndent (U.K.), June 27, 2009, available at http://www.independent.co.uk/news/world/europe/the-last-days-of-the-court-of-kingsilvio-1721558.html.

78. It is theoretically possible that the inclusion of less than serious candidates drives turnour down, rather than up. If there were gains from running ordinary politicians, however, we would expect the 
three percent of European voters voted, turnout has continuously fallen. ${ }^{79}$ Approximately twenty percentage points lower than the average turnout in national elections, it dropped to under fifty percent participation for the first time in 2004 and was only at forty-three percent in $2009 .{ }^{80}$ Moreover, this actually overstates the actual enthusiasm for voting in EP elections, as it includes data from countries, such as Belgium, where voting is mandatory, and countries that held simultaneous local elections. ${ }^{81}$ The turnout was particularly low in some member states-under twenty percent in Slovakia, twenty-one percent in Lithuania, and thirty-five percent in the UK. ${ }^{82}$ European voters generally turnout in high numbers, but cannot be bothered to do so in EP elections.

Even more problematic for the democratic theory underlying the EP than who votes is who wins, and more specifically, why they win. If the EP is supposed to provide the EU with popular input about EU policymaking, at the very least two things are required: first, that EU policy be considered when voting decisions are made; and second, that the positions of the parties on EU policies have an effect on who wins. Neither is currently the case.

It is relatively clear that neither EP campaigns nor their results have much to do with the work of the institution. Campaigns are largely waged around domestic issues. ${ }^{83}$ Scholars from The University of Sussex Institute's European Parties, Election \& Referendums Network studied the content of each EP campaign in twenty-one of the twenty-seven member states in $2004 .^{84}$ Their reporters found that EU issues played virtually no role in

parties to do so in order to reap the electoral benefits. As it stands, there is little evidence that it matters at all who is on the ballot.

79. Alexander C. Pacek \& Benjamin Radcliff, Voter Participation and Party-group Fortunes in European Parliament Elections, 1979-1999: A Cross-National Analysis, 56 Pol. Res. Q. 91,92 (2003); see also HIx, What's WRONG, supra note 3, ar 80.

80. See Hix, What's Wrong, supra note 3, at 80; Turnout at the European Elections, European EleCTIONS RESULTS 2009, http://www.europarl.europa.eu/parliament/archive/elections2009/en/turnout_en. html (last visited Oct. 1, 2010) (showing that turnout was forty-three percent).

81. Judy Demspey, For East Europeans, the E.U. Election Was a Big Yaun, InT'L Heraid Trib., June 9, 2009 , available at http://www.nytimes.com/2009/06/10/world/europe/10ihtvote.html?scp $=1$ \&sq $=$ for\% 20East $\% 20$ Europeans, $\% 20$ the $\% 20 \mathrm{EU} \% 20$ election $\% 20$ was $\% 20 \mathrm{a} \% 20 \mathrm{big} \% 20$ yawn\&st $=$ cse (stating that Latvia's turnout was 30 percent higher than Lithuana's, largely because of local elections); Matthew Taylor, Flying the Flag for Apathy, GuARDian (U.K.), June 9, 2009, available at http://www.guardian.co. uk/politics/2009/jun/08/vorer-turnour-liverpool; Turnout at the European Elections, supra note 80 (stating that Belgium and Luxembourg had turnout over ninety percent.)

82. See Turnout at the European Elections, supra note 80.

83. See Chalmers, et Al., supra note 35, at 111-12.

84. European Parliament Elertions, European Parties Elections and Referendums Network, SusSEX EUROPEAN INSTITUTE, UNIVERSITY OF SuSSEX, http://www.sussex.ac.uk/sei/"-4-2-2.html (last visited Nov, 11, 2010) (listing a series of Euopean Parliament election briefings). Dan Hough, the analyst that studied the German elections, wrote: "The election held to elect 99 German representatives to the European Parliament was always likely to be hijacked by affairs specific to the national arena. European themes played, at best, an occasional role in the campaign - at worst they were completely insignificant." Dan Hough, 2004 Parliament Election Briefing No. 3: The European Parliament Election in Germany, June 13, 2004, available at http://www.sussex.ac.uk/sei/documents/epernep2004germany.pdf (last visited Nov. 11, 2010). The analyst covering Poland, Aleks Szczerbiak, wrote: "European issues played a secondary role in a dull and lifeless campaign to which the main parties and media gave a very low priority and 
fifteen of the twenty-one campaigns. In three others-Denmark, Britain, and Sweden-there was campaigning built around major (and minor) party stances that were simply either pro- or anti-EU. ${ }^{85}$ Only in three countriesFrance, Ireland, and the Netherlands-was there any discussion about the substance of EU policy. ${ }^{86}$

The 2009 election does not appear to be different. In the UK, a scandal caused by expenses charged to the government by members of the national parliament dominated election campaigns. ${ }^{87}$ In Italy, the Prime Minister's alleged extramarital affairs and corruption problems were the top campaign issues. ${ }^{88}$ The German elections were seen and treated by the parties as a dress run for the next year's domestic elections. ${ }^{89}$ The Sussex Institute studies for 2009 show the same results: in all but a few countries, European issues either were not featured at all or received extremely little attention relative

that was overshadowed by a government formation crisis and possibility of an early parliamentary election." Aleks Szczerbiak, 2004 European Parliament Election Briefing No. 1: The European Parliament Election in Poland, June 13, 2004, available at http://www.sussex.ac.uk/sei/documents/epernep2004poland.pdf (last visited Nov. 11, 2010).

85. See Nicholas Aylott \& Magnus Blomgren, 2004 European Parliament Election Briefing No. 7: The European Parliament Election in Sweden, June 13 2004, available at http://www.sussex.ac.uk/sei/documents/ epernep2004sweden.pdf (last visited Nov. 11, 2010); Ann-Christina L. Knudsen, 2004 European Parliament Election Briefing No. 11: The European Parliament Election in Denmark, June 13 2004, available at http:/ /www.sussex.ac.uk/sei/documents/epernep2004denmark.pdf (last visited Nov. 11, 2010); Paul Taggart, 2004 European Parliament Election Briefing No. 14: The European Parliament Election in the United Kingdom, June 10 2004, available at http://www.sussex.ac.uk/sei/documents/epern-ep2004-uk.pdf (last visited Nov. 11, 2010). The studies reveal that in countries where EU issues play virtually no role, the only EUcentric content is centered around competing claims that parties can get more money from Brussels. For instance, in the largely European-issue-devoid German EP elections of 2004, the Free Democratic Party used the slogan "We can do Europe better." Hough, supra note 84, at 7 . The only European issue mentioned in the EP campaign in Hungary was the claim, made by all four major parties, that they would maximize transfer from Brussels to Budapest. Agnes Batory, 2004 European Parliament Election Briefing No. 8: The European Parliament Election in Hungary, June 13 2004, available at http://www. sussex.ac.uk/sei/documents/epernep2004hungary.pdf (last visited Nov. 11, 2010). This is common throughout the reports.

86. See Robert Harmsen, 2004 European Parliament Election Election Briefing No. 17: The European Parliament Election in the Netherlands, June 10, 2004, available at http://www.sussex.ac.uk/sei/documents/ epern-ep2004-netherlands.pdf (last visited Nov. 11, 2010); Michael Holmes, 2004 European Parliament election Briefing No.2: The European Parliament Election in Ireland, June 11 2004, available at http://www. sussex.ac.uk/sei/documents/epernep2004ireland.pdf (last visited Nov. 11, 2010); Sally Marthaler, 2004 European Parliament Election Briefing No. 6: The European Parliament Election in France, June 132004 , available at htrp://www.sussex.ac.uk/sei/documents/pernep2004france.pdf (last visited Nov. 11, 2010).

87. Ben Quinn, European Elections Pound Britain's Brown, Christinn SCI. Monitor, June 8, 2009, at 4 (quoting a political scientist as saying "In my liferime there has been never been an election so dominated by one issue to the of [sic] extent of the expenses issue.").

88. The New EP-National Impart, THENEwEP.EU (July 16, 2009), http://thenewep.com/nationalstare-of-play/. ("[Italy's] electoral campaign, which started quite late (at the beginning of May), did not focus on EU-related issues, but was mainly characterised by scandals, personal attacks and gossip, widely publicised by the media both at national and international level.").

89. Id. ("There was low interest in the European elections among German voters and consequently a historically low voter turnout of forty-three percent. As in the past, campaigns mostly focused on national issues and national politicians."). 
to domestic issues. ${ }^{90} \mathrm{EU}$ policy is simply not very important in EP election campaigns.

Similarly, the results of EP elections also have little to do with voter opinions about European policy. The central finding of the last twenty-five years of studying EP elections is that they are "second-order national contests." 91 That is, voters use these elections to comment on their current domestic government, or, put another way, EP elections are a referendum on a country's prime minister. This effect is stronger in some places, such as those member states with histories of alternating government rather than governance by grand coalition, but domestic politics nevertheless remain the largest determinant of voting in European elections in all European countries. ${ }^{92}$ This finding is extremely robust. That EP elections are "second order" is the central and probably only generally agreed upon finding in the scholarship on EU politics. ${ }^{93}$

Moreover, there is no evidence that the votes, speeches, and promises made by MEPs affect EP elections at all. While it is possible that there might be some small exceptions to this rule-some observers credit the Green Party's strong EP election performance in France to the personality and politics of Daniel Cohn-Bendit, the former 1968 radical who leads the party in the EP-virtually nothing that happens in Strasbourg matters in the voting booth. ${ }^{94}$ The campaign trail is the same: all evidence suggests that voters are unaware of any European issues in these elections, and EP campaigns do not help them decide how to vote. 95

The only way the results of EP elections systematically differ from national ones is that small parties tend to slightly over-perform.

[A]nti-EU parties and green parties on average do better in European elections than in national elections. But these 'European effects' are minor. Hence, despite the growing powers of the

90. Even in those countries where European issues did feature in the campaign, they were not decisive. For instance, in the Netherlands, where there was a grear deal of pro- and anti-European rhetoric in the campaign, domestic issues determined the results nearly entirely. See Stijn van Kessel, The European Parliament Election in the Netherlands, June 42009 , available at http://www.sussex.ac.uk/sei/documents/ no_28_epern-ep09_-netherlands.pdf (last visited Oct. 5, 2010). In Finland, "defending national interests" was the major theme, and in Malta, Sussex's analyst noted that it was difficult to determine what is European policy and what is domestic policy, as the two are substantially intertwined. See Roderick Pace, The European Parliament Election in Malta, June 6 2009, available at htrp://www.sussex.ac.uk/sei/ documents/no_27_epernep2009malta.pdf (last visited Oct. 5, 2010); Tapio Raunio, The European Parliament Election in Finland, June 7 2009, available at http:/www.sussex.ac.uk/sei/documents/epern-ep09_finland_ep.pdf (last visited Oct. 5, 2010).

91. The Poutical System, supra note 40, at 193-96.

92. Marsh, Testing the Second-Order Election Model After Four European Elections, supra note 3, at 606.

93. Id.; see also Hix, What's Wrong, supra nore 3, at 79-80; Simon Hix \& Michael Marsh, Punishment or Protest? Understanding European Parliament Elections, 69(2) J. PoL. 495, 495-96 (2007).

94. Archie Bland \& Toby Green, How Europe Voted and What it Means, InDEPEndent (U.K.), June 9, 2009 at 12 (crediting green party's French success to Cohn-Bendit); John Lichfield, Danny the Green: Daniel Cobn+Bendit, InDEPENDENT (U.K.), June 13, 2009, at 36.

95. Marsh \& Franklin, supra note 71 , at 24-28. 
European Parliament, neither positions on matters regarding European integration, nor on matters regarding 'normal' left-right policy, have much of an effect on electoral outcomes. ${ }^{96}$

Although there is little solid evidence explaining these small parties' over-performance in these elections, their successes are consistent with the evidence suggesting that most voters know and care little about EP elections. In the absence of knowledge about the actual performance or positions of parties, one would expect parties with single-issue messages that are clear from their names (it does not take much outside knowledge to know what the United Kingdom Independence Party or the Green Party advocates) to have an advantage in attracting low-information votes.

The 2009 EP elections followed the usual script. Burson-Marsteller, the large public relations and lobbying firm, hired several prominent political scientists to design a model to predict the EP elections. Their model started with preferences about national parties without any reference to the EP.97 The reason for this was simple: "Opinion polls for European Parliament elections are less accurate than opinion polls for national elections. This is because voters are usually thinking about national elections when answering European election polls." 98 With only some small tweaks related to minor party votes, the model was able to predict ninety-eight percent of the seats by Euro-party, and ninety percent of the seats won by each national party. ${ }^{99}$

In 2009, center-right parties received the majority of seats in EP elections in most of the larger European countries, including Britain, France, Germany, Italy, and Spain. ${ }^{100}$ However, this was not a result of increased support for center-right parties-support for major center-right parties barely changed-but rather reflects the voter loss of center-left parties to far right, liberal and green parties throughout Europe. ${ }^{101}$ Most notable was the success

96. Hix \& Marsh, supra note 93 , at 495 . The best explanation for the success of small parties is that some voters feel free to cast a protest vote when there is little chance that the popular vote will affect the composition of domestic government. See Erik Oppenhuis et al., The Party Context: Outcomes, in Choosing Europe? The European Electorate and National Politics in the Face of Union 288-89 (Cees van der Eijk \& Mark Franklin eds., 1996).

97. Burson-Marsteller, Predict '09 Methodology, June 4, 2009, http://qa.predict09.host3.crossfactory. net/default/en-us.aspx (last visited Nov. 9, 2010).

98. 1 ld.

99. The reason the numbers are different is that there was some tradeoff. For instance, the model's prediction was low by one seat the support for the conservatives in Finland, but was high by one in Germany. Burson-Marsteller, Predict '09 Executive Summary, June 16, 2009, http://qa.predict09.host3. crossfactory, net/default/en-us.aspx.

100. See Swing Low, Swing Right, supra note 2.

101. See Ian Traynor, Defiant or in Denial? Champions of EU Progress Stopped in Their Tracks, Guardian (U.K.), June 9, 2009, at 6, available at http://www.guardian.co.uk/world/2009/jun/08/centre-lefteuropean-elections (quoting Simon Hix as saying "The centre-right won the election, but it [their vote] did not really go up . . . [i]t's the centre-left that has gone down, in government or in opposition" and noting that "[w]herever the centre-left collapsed, the extreme right frequently scored its most spectacular gains-in Hungary, Austria, the Netherlands and Britain. But pro-EU left liberals and Greens also did well."); see also Swing Low, Swing Right, sutpra note 2 ("Support for mainstream centre-right parties held steady or fell slightly."). 
of small parties. The radical anti-European United Kingdom Independence Party won two MEP seats in Britain, the Greens nearly outpolled the Socialists in France, anti-Muslim and immigration parties won seats in the Netherlands and Belgium, an anti-Roma party did well in Hungary, and a pro-internet piracy party won a seat in Sweden. ${ }^{102}$

Although center-right parties did well across Europe, it is hard to understand this result as a common position on what the EU should do. National issues dominated EP election campaigns, and center-right parties (as well as center-left parties) across Europe have diverged tremendously on major questions of the day, like the amount of government economic intervention is necessary following the economic crisis. ${ }^{103}$ Further, even if European voters have common preferences about what their national governments should do, it is unclear why or whether these translate to preferences about European regulation. EU legislation generally replaces or stands in for national regulations, meaning that EU regulation that is relatively pro-market in France may involve more regulation than currently exists in the UK. ${ }^{104} \mathrm{Fi}-$ nally, it is clear that all sorts of factors affect EP elections-like the UK expenses scandal-that are completely irrelevant to what the EP does. As such, it is hard to understand the results of these elections as reflecting much about voters' EU policy preferences. ${ }^{105}$

As campaigns have little impact on who is elected, it is unsurprising that they have little effect on elected MEPs once they are in power as well. European issues do not figure much in EP campaigns, and when they do, it is the national interest, and not right/left ideologies about European regulation, that are mentioned. ${ }^{106}$ However, when voting in the EP, MEPs toe ideological party lines with respect to EU policy, and national issues are muted.

102. Stephen Castle, Disaffection Dominates European Voting, N.Y.Times, June 8, 2009, at A5, available at http://www.nytimes.com/2009/06/08/world/europe/08union.html; Trouble at the Polls: The Worrying European Elections, Economist, June 13, 2009, available at http://www.economist.com/node/13829453 ?story_id=13829453. For full results by party, see Results of the 2009 European Elections, http:/www. europarl.europa.eu/parliament/archive/elections $2009 / \mathrm{en} / \mathrm{new}$ _parliament_en.html (last visited Nov. 6, 2010) (listing 2009 EP election results by country by party).

103. See, e.g., Katrin Benhold \& Stephen Castle, European Leaders Looking for Common Ground in an Economic Crisis, N.Y.Tımes, Nov. 25, 2008, at 7, available at http:/www.nytimes.com/2008/11/2/ business/worldbusiness/25euro.html (center-right leaders in France and Germany disagree on proper European response to economic crisis); Arthur Sinodinos, Pragmatists the Voters' Cboice, Australuan, June 12, 2009, available at http:/www.theaustralian.com.au/news/opinion/pragmatists-the-voters-choice/storyfn5r96n6-1225733474748; Patrick Wintour, Brown and Sarkozy Nudge Germans Towards Fresh Economic Measures, Guardian (U.K.), Dec. 9, 2008, at 11 (center-left British PM, center-right French President and center-right European Commission President all agree on stimulus but disagree with center-right German prime minister).

104. See Young, supra note 7, at 1672 (describing how EU laws "trump" domestic laws).

105. It should be noted that there is likely a substantial correlation in what voters think abour domestic politics and what they think about EU politics. However, that correlation is certainly not very tight-plenty of factors affecting domestic party preferences are irrelevant to EU decisionmaking. Furthermore, the absence of campaigning on EU issues means that there is little retrospective accountability. Voters may select politicians based on preferences that correlate with their preferences on EU issues, but they do not police MEP behavior once they get to Strasbourg.

106. See supra note 90 and accompanying text. 
MEPs of like-minded domestic parties join in common caucuses. In the first elected EP, there were three major coalitions-a Christian Democratic coalition called the European People's Party and the Socialists, a Social Democratic coalition, and a somewhat smaller coalition of liberal parties. ${ }^{107}$ Several other groups formed over time-some were "coalitions" that actually comprised of one or two national parties, others were odd pairings of non-ideologically aligned groups, and others were true multinational, ideologically consistent groupings. ${ }^{108}$ These caucuses grew into real organizations-separate legal entities with substantial budgets provided by the EU. ${ }^{109}$ There are now eight major Euro-parties: the European People's Party, which includes members from most mainstream center-right parties in Europe, the Party of European Socialists, the Alliance of Liberals and Democrats for Europe (liberals and centrist parties) and parties representing Far Leftists-Nordic Greens, Regionalists, Greens, hard tight anti-Europeans, and a new bloc consisting of anti-European mainstream conservative parties from the UK, the Czech Republic, Poland, and others. ${ }^{110}$

Given their lack of electoral mandate, these Euro-parties are remarkably ideologically coherent. Simon Hix, a leading EP scholar, studied roll call data in the EP and has shown that Euro-party cohesion (common voting among party members) has increased even as the number of countries represented in each party has also increased. ${ }^{111}$ Further, the main division among the parties is left-right ideology, not national competition. "Left-right politics explains an overwhelming proportion of voting in the European Parliament. In contrast, national interests, independent of national party positions, have very little systematic influence on voting in the European Parliament." 112 This is particularly odd, given that when European issues are raised in EP elections, it is almost always parties making claims about their superior ability to bring home resources or to make the EU work better for their home country. ${ }^{13}$

It is thus little wonder that voters fail to turn out, nor that the introduction of elections to the EP fails to confer much democratic legitimacy on the $\mathrm{EU}$ as a whole. The EU funds the highly respected Eurobarometer polls, which study popular opinion across Europe by conducting 1000 interviews in each member state. ${ }^{114}$ In 1979 , before the introduction of direct elections

107. See Democratic Politics, supra note 4 , at $21-29$.

108. Id.

109. See Day \& Shaw, supra note 67 , at $296-97$.

110. Democratic Politics, supra note 4, at 23, 26; Nicholas Watt \& Ian Traynor, Tories Head New Rightwing Fringe Group in Europe, Guardian (U.K.), June 23, 2009, at 13 (discussing new Euro-party).

111. Democratic Politics, supra note 4 , at 104.

112. $I d$. at $180-81$.

113. See supra note 85 and accompanying text.

114. Hix, What's Wrong, supra note 3 , at 51 . There are only a few exceptions to the 1000 interviews per country rule. The EU funds 2000 interviews in Germany, 1300 in the UK, and 600 in Luxembourg. See Standard Eurobarometer 70, EUROPEAN COMMISSION, http://ec.europa.eu/public_opinion/ archives/eb/eb70/eb70_en.htm (last updated June 7, 2010). 
to the EP, support for the EU-as measured by whether respondents thought membership was beneficial for theit country-was fifty-nine percent. ${ }^{115}$ By 1991, it had risen to seventy-two percent. ${ }^{116}$ However, between 1991 and 1996, the period during which the EP's power grew most dramatically following the Maastricht Treaty, support dropped to just over fifty percent, where it has, with a few bumps, stayed. ${ }^{117}$

Some scholars have claimed that the failures of EP elections have caused this drop in legitimacy. ${ }^{18}$ They claim that before the EP was given substantial power, European citizens believed that member states controlled the $\mathrm{EU}$, but that when the EP became a symbol of an independent EU, citizens became disappointed with the absence of democratic accountability. However, there are reasons to doubt this causal story. In Eurobarometer polls, European citizens report that they trust the EP slightly more than they do other EU institutions. ${ }^{119}$ Nonetheless, empowering the EP has not increased the degree to which EU citizens support their country's continued membership in the EU, nor has it stopped complaints about a democratic deficit. Yves Meny has noted that "the democratic deficit argument never raged as much as it did after the election of MEPs by universal suffrage."120

The problems of EP elections have left the EP unable to fulfill its role in the EU institutional structure. The EP is supposed to be a popularly chosen pan-European body that checks the influence of the bureaucratic Commission and the member-state controlled Council. Instead, it is a highly bureaucratic body selected on the basis of member state politics without any reference to EU issues. The goal of creating a three-part balance of powers is a failure, and EP elections are the cause of that failure.

\section{European Parliament Elections as an Institutional Problem: The Conflict Between Reform and the Existing Separation of POWERS INSIDE THE EUROPEAN UNION}

The problems of the EP, and of the EU's "democratic deficit" more generally, have generated much debate and many proposals for how they may be

115. Comm'n of the European Communities, Standard Eurobarometer 11: Public Opinion in the European Community, at 44 (May 1979), available at http://ec.europa.eu/public_opinion/archives/eb/eb11/eb11_en. htm.

116. Comm'n of the European Communities, Standard Eurobarometer 35: Public Opinion in the European Community, at 3 (June 1991), available at http://ec.europa.eu/public_opinion/archives/eb/eb35/eb35_en. htm.

117. Standard Eurobarometer 70 , supra note 114 , at 31; Hix, WHAT's WRONG, supra note 3, at 52-53.

118. See, e.g., Mark Franklin \& Cees van der Eijk, The Problem: Representation and Democracy in the European Union, in Choosing Europe? The European Electorate and National Polutics in the FACE of UNION, supra note 71 , at 7-8.

119. In the last Standard EuroBarometer poll, fifty-one percent "tended to trust" the EP, while only forty-seven percent and forty-eight percent "tended to trust" the European Commission and the European Central Bank, respectively. Standard Eurabarometer 70, supra note 114, at 165 .

120. Yves Meny, De la Demacratie en Europe: Old Concepts and New Challenges, $41 \mathrm{~J}$. Common MKт. STUD. 1, 8 (2003); see also Sieberson, supra note 56, at 204-05. 
solved. The literature on the democratic deficit is vast and varied, perhaps the most studied subject in European politics in the last thirty years. ${ }^{121}$ Rather than address the entirety of this literature, it makes more sense to look at the two leading entrants in the debate over the democratic deficit. ${ }^{122}$ Although they differ substantially in prescription, both from each other and from the existing efforts of the EU to respond to the problems of EP elections, they have something central in common.

Simon Hix and Andrew Moravcsik have developed opposing analyses of the problem (or lack thereof) of democracy in the EU. Each of them promotes a very different vision of what the EU should do to resolve the fact that EP elections do not provide much democratic input into EU decisionmaking. Moravcsik proffers that European citizens are simply wrong to worry about democratic input in the EU, effectively rejecting the importance of the EP's stated role. Hix goes in the entirely opposite direction, suggesting that much, if not all, of the EU governing structure should be determined by European elections, with the composition of the Commission turning on EP results and the Council dividing along partisan grounds as well. Although neither proposes changes to the treaties that give the EU its institutional form, both call for agreement among political elites to effectively nullify the separation of powers envisioned by European leaders when they designed the EU's institutions. Thus, both arguments effectively call for changing the institutional arrangements of the EU by widespread elite agreement.

121. Indeed, the number of times it has been suggested that the literature on the EU and its democratic deficit is too large to summarize is itself too large to summarize. For a few examples from recent legal literature, see, e.g., Rachel Brewster, The Domestic Origins of International Agreements, $44 \mathrm{VA}$. J. INT'L L. 501, 543 (2004) ("Such concerns about a 'democratic deficit' are commonly heard with regards to the European Union, where the power of national governments to act in numerous areas has been restricted by treaty obligations."); Youri Deyvust, The European Union's Institutional Balance After the Treaty of Lisbon: "Community Method" and "Democratic Deficit" Reassessed, 39 Geo. J. INT'L L. 247, 254 (2008) ("The literature from political scientists debating the existence and scope of the "democratic deficit" in the EU is rich."); Daniel C. Esty, Good Governance at the Supranational Scale: Globalizing Administrative Law, 115 YALE L.J. 1490, 1515 (2006) ("The EU's democratic deficit, for example, has become a major topic of scholarly discussion and similar concerns have been focused on other supranational governance efforts."); Sanford Levinson, How the United States Constitution Contributes to the Democratic Deficit in America, 55 Drake L. Rev. 859, 860 (2007) ("There are more than 500,000 hits that come up when one uses Google to search for 'democratic deficit'-revealing that it is especially pervasive in discussions of the European Union and the general project of European integration."); Jan Muller, Carl Schmitt and the Constitution of Europe, 21 Cardozo L. Rev. 1777, 1778 (2000) ("Secondly, there is the old, and, one might say, by now rather trite, issue of the 'democratic deficit.' "); Martin Nettesheim, Developing a Theory of Democracy for the European Union, 23 Berkeley J. INT'L L. 358, 358 (2005) ("The number of books and articles expounding upon the problem of whether or not the European Union (EU) presents a 'Democratic Deficit' and if so whether and how this may be overcome, has become nearly too numerous to count."); Neil S. Siegel, International Delegations and the Values of Federalism, 71 LAw \& Contemp. Pros. 93, 103 (2008) ("This is of course familiar learning by now. Commentators have written increasingly about the 'democratic deficit' that characterizes international institutions, particularly the European Union.").

122. See, e.g., Luciano Bardi, Parties and Party System in the European Union: National and Suprantional Dimensions, in Political Parties in the New Europe: Political and Analytical Challenges 293, 293 (Kurt Richard Luther \& Ferdinand Muller-Rommel eds., 2002) (describing Hix and Moravcsik as having "revitalized the theoretical debate" about the study of democracy in the EU). 
These arguments in favor of tacit amendment rely on a common assessment that the reality of current EU politics is not achieving the goals behind the logic of its system of separation of powers. This same belief is inherent in the EU's repeated decisions to allocate more power to the EP, which were intended to make it powerful enough that people cared about it. This section will show that the current debates over the EP assume that the failure of its elections requires a change in the logic of the EU's system of separation of powers. The next section will argue that this assumption is not necessary.

After writing his views on democracy in the EU over the course of a decade, Moravcsik concentrated them into a remarkable article: "In Defense of the 'Democratic Deficit': Reassessing Legitimacy in the European Union." 123 Its central argument is that the impression, which many European cirizens share, that Europe lacks democratic legitimacy is simply wrong. "Concern about the EU's 'democratic deficit' is misplaced."124

The first error of the critics that denounce EU's democratic legitimacy, he argues, is that they ignore what the EU does. Unlike the undemocratic super-state it is sometimes painted as, the EU makes policy in only a limited number of areas, mostly regulating cross-border economic effects. Moreover, it does not implement most of its own regulations, leaving that to member states. The EU also has a small budget, just over one percent of the EU's GDP, rendering it incapable of either redistributing incomes or engaging in many of the other ordinary activities of a modern regulatory state. ${ }^{125}$ The areas in which it does make policy (e.g. international trade, anti-trust, and consumer protection) are low salience, and governments often make these decisions at some level of removal from voters. ${ }^{126}$ The EU "simply specializ[es] in those functions of modern democratic governance that tend to involve less direct political participation." 127 When the nature of the issues addressed by EU policy is taken into account, the lack of direct voter involvement in EU policymaking looks less problematic.

Second, Moravcsik notes that there is a great deal of democratic input into European decisionmaking. EU policymaking requires a great deal of consensus, as there are a number of checks and balances imbedded in the various majorities and super-majorities needed to get legislation through the Commission, the Council and the EP. This mitigates the failings of EP elections. As Moravcsik states:

123. Andrew Moravcsik, In Defense of the 'Democratic Deficit': Reassessing Legitimacy in the European Union, 40 J. COMMON MKT. STUD. 603 (2002).

124. Id. at 603.

125. Id. at 608 .

126. Id. at 616. One might quibble, however, with his determination that international trade is a low-salience issue.

127. Id. at 606. The strongest EU institution, the European Central Bank, is a perfect example of his point. After all, central banks are often independent and free of any direct democratic input. 
Whereas one might criticize the absence of clear programmatic elections, the EP nonetheless has an effective system of party cooperation, with votes most often split along party lines and recognizable ideological cleavages shaping voting patterns. Among the most relevant differences between the European Parliament and national parliaments appears to be the tendency of the EP to reach decisions by large majorities. Yet this tendency underscores the tendency of the EU to reach decisions by large majorities . . . unsurprising given the high level of support required in the Council of Ministers-and should give us reason for confidence that it is legislating in the 'European' interest. ${ }^{128}$

Finally, and most importantly, all policy must be favored by a large majority of democratically-elected state governments in the Council. Talk of a democratic deficit is misplaced not only because the EU acts only in certain areas, but also because it only acts when there is broad consensus across European political players.

Moravcsik provides a powerful defense of the EU as an institution, but he does not address the narrower question of how to solve the problem of the EU's alleged democratic deficiency. Unless simply telling voters that they are wrong to be worried about the democratic legitimacy of the EU is an effective strategy, more is needed if the EU wants to garner greater popular support. Further, and more importantly for the purposes of this Article, Moravcsik's argument for inaction in the face of EP elections' failure to produce direct democratic input is effectively a call to revise the normative underpinnings of the separation of powers in the EU. If the EP is supposed to provide a balance to the role of the Council and Commission, and it is not doing so, then claiming that there is no problem is a suggestion that the theory of separation of powers in the EU is flawed.

Hix approaches this problem from a very different perspective but similarly calls for revising the separation of powers in the EU. ${ }^{129} \mathrm{He}$ argues that the EU currently suffers from two problems-gridlock and lack of electoral competition-and the resulting political stasis has caused more and more Europeans to question whether it is good for their country to be a member of the EU. The increased size and ambit of the EU, due to the addition of new members and the increased number of areas in which it is allowed to set policy, have created problems for its current decisionmaking apparatus. ${ }^{130}$

128. Id. at 612 .

129. Hix developed these ideas in a series of articles as well, one of them notably written directly in response to Moravcsik's paper, as well as a recent book. See generally HIx, WHAT's WRONG, supra note 3; Andreas Follesdal \& Simon Hix, Why There is a Democratic Deficit in the EU: A Response to Majone and Moraucsik, 44 J. Common Mkr. Stud. 533 (2006); Simon Hix, Elections, Parties and Institutional Design: A Comparative Perspective on European Union Democracy, 21 WeST EURO. Pol. 19 (1998); Simon Hix, Parties at the European Level and the Legitimacy of EU Socio-Economic Policy, 33 J. Common MKr. Stud. 527 (1995). 130. Hrx, What's WrONG, supra note 3 , at 31-49. 
Further, as Part I.B discusses, EP elections are not truly European but national instead. ${ }^{131}$ This means that the only true way voters have of expressing their beliefs about Europe is through their domestic governments, and EU issues only make up a part of the domestic agenda. The result is that voters are unable to express opinions about the future of the EU. This lack of voice in the EU is what is driving the desire for exit, and is why, Hix claims, popular support for EU membership has fallen. ${ }^{132}$

Hix argues that neither the EU nor the EP will function well until there is true pan-European partisan political competition. To support these claims, he invokes the standard (and extremely persuasive) arguments about partisan competition in all contexts. Introducing partisan competition would: (1) promote policy innovation, as parties would have an incentive to develop new ideas in order to get votes; (2) permit the formation of crossinstitutional coalitions, which is particularly important for solving gridlock in the EU; (3) generate media coverage; (4) give citizens a heuristic for expressing policy views, which would encourage the development of opinions about European politics; and (5) create a mandate for policy change. ${ }^{133} \mathrm{Hix}$ also argues that "perhaps most profoundly, democratic politics leads to the formation of new political identities." 134 Europeans will become more European in their understandings of politics and their self-identification (and correspondingly less French, German, British, etc.) if they engage in the type of collective democratic decisionmaking that common pan-European parties would enable.

Creating such competition would not require formal changes in the treaties that give the EU its organizational shape. Hix proposes two reforms. First, positions of power inside the EP are divided among all parties, and Hix argues that if the party forming the majority of EP were granted more power to name officials in the Parliament, it would encourage more aggressive electoral politicking. ${ }^{135}$ Acknowledging that this is unlikely to accomplish much, he proposes a much more dramatic solution: using the current system to create an effectively direct election for the Presidency of the European Commission. ${ }^{136}$ This could be achieved if the Euro-parties (and their national party members) agree on candidates for Commission President before the election. If these candidates then behaved like American presidential candidates, they would create enough media and public support to get voters interested in European elections. Agreement by national party leaders, who vote in the Council (when they are in power domestically) and have

131. Id. at $76-86$.

132. Id. at 65-66. Hix does not expressly use Albert Hirschman's terminology of exit and voice, but the idea is similar. See Albert O. Hirschman, Exit, Voice, and Loyalty: Responses to Decline in Firms, Organizations, and States 40-41 (1970).

133. Hix, What's WRONG, supra note 3, at 98-107.

134. Id. at 105 .

135. Id. at 140 .

136. Id. at $155-78$. 
the power to nominate the Commission President, in conjunction with Euro Party groups could permit this even without revision to the governing treaty. ${ }^{137} \mathrm{Hix}$ also thinks the Council should behave in a more openly partisan manner. ${ }^{138}$

These proposals are intriguing, despite being full of practical problems. For instance, his proposal calls for widespread agreement from all the component parties of the pan-European parties about candidates for Commission President without explaining what their incentives for doing so are. Further, his system would recreate some of the problems of the U.S. Electoral College, because small countries are overrepresented in the EP and as a result, the popular vote winner would not necessarily be elected. ${ }^{139}$

Even so, $\mathrm{Hix}$ is convincing when he argues that true mass membership in pan-European parties would be a powerful force for integration, making the EU more dynamic on policy and the elections clearer for voters. Further, he may be right that pan-European parties would help create a pan-European "demos." However, there is little evidence that this is what anyone in Europe wants. The proposal would largely undo the current separation of powers in the EU. By making the Commission turn on EP elections and the Council more partisan, it would remove the balance at the heart of the EU's institutional structure. Rather than having different interests represented in different parts of the government, Hix would have direct representative democracy at the European level decide all EU policy.

One might agree with either Hix or Moravcsik, but it ultimately requires a determination about the relative importance of pan-European popular representation and political identities versus protecting member state autonomy and national political identities. What both presuppose is that the current system of allocating power, in which the EP is supposed to play a popular democratic role in a complex separation of powers, is flawed and cannot be fixed.

I disagree, or at least think there is no reason yet to believe that this is so, as the next section will make clear.

137. Id. at 160 .

138. Id. at 153.

139. See Marcus G. Puder, Constitutionalizing Government in the European Union: Europe's New Instituitonal Quartet Under the Treaty Establisbing a Constitution for Europe, 11 Colum. J. EUR. L. 77, 92 (2004) (describing over and underrepresentation by population in the EP). Germany is particularly underrepresented by population in the EP. For instance, there is one German MEP for every 829,000 inhabitants, while there is one MEP from Luxembourg for every 72,000 inhabitants. Id. 


\section{European Parliament Elections as a Mismatch Problem: Using Election Law to Make the European Parliament Play its Institutional Role}

Whereas Hix, Moravcsik and European leaders all see the failures of EP elections and move directly to the question of why the separation of powers in the EU is flawed, there is another way to respond. Rather than responding to the failure of elections by changing the institutional structure of the EU (or undermining it withour formally changing it), EU leaders could attempt to change the way elections are contested to bring them into line with the institutional goals of the EU.

Election systems are not neutral. The laws that govern elections in many ways dictate the way elections are contested, if not the results directly. For instance, election systems that use single-member districts and "first-pastthe-post" vote counting (like all federal and almost all state and local elections in the United States) trend towards having only two political parties. Political scientists call this Duverger's Law. ${ }^{140}$ Because voters and supporters hate to waste their votes and efforts, they abandon third party candidates to focus on the two most viable candidates. By using a first-past-the-post system, the United States ensures a clear choice between two centrist alternatives.

Similarly, the voting system used for EP elections ensures that the elections will be "second-order": domestic politics will matter more than European politics in determining who wins elections. More specifically, the interaction between the election laws used, rationally ignorant voters, and the competitive state of play among domestic parties explains why EP elections are second order. EP ballots do not provide voters with heuristics that track performance in the EP, and leave voters, who have little direct knowledge of individual MEP voting patterns, without the ability to cast ballots that track their preferences on European issues. The result is elections that do not achieve the goals underlying the decision to hold EP elections.

This does not have to be so. The EU could change the election law system to make EP elections turn on European issues. By requiring political parties to get a certain threshold amount of the vote in a majority of EU countries in order to get any members elected from any country, the EU could force

140. It is called Duverger's Law following the classic work of Maurice Duverger. See generally Maurice Duverger, Political. Parties: Their Organization and Activity in the Modern State (Barbara North \& Robert North trans., Lund Humphries 2d ed. 1959); William H. Riker, The Two-Party System and Duverger's Law: An Essay on the History of Political Science, 76 AM. PoL. SCl. Rev. 753, 764 (1982). There is substantial debate about the degree to which Duverger's Law is deterministic, probabilistic and/or causal. See William H. Riker, Duverger's Law Revisited, in Electoral Laws and TheIr Pourrical Consequences 19, 19-42 (Bernard Grofman \& Arend Lijphart eds., 1986). For an argument that Duverger's Law has a normative component, see David Schleicher, 'Politics as Markets' Reconsidered: Natural Monopolies, Competitive Democratic Philosophy and Primary Ballot Access in American Elections, $14 \mathrm{~S}$. CT. ECON. Rev. 163, 168-70 (2006). 
campaigns to be waged at the European, rather than the member state, level. Further, by doing so, it could give voters the means of determining whom in Europe to hold responsible for EU actions, something that the current system does not permit.

\section{A. The problem of mismatch in European Parliament elections}

The EU clearly intended for EP elections to provide European voters with the ability to comment directly on EU policy. They do not do so. The problem of EP elections is similar to one that has been diagnosed in several places in the American context: a "mismatch" between the constitutional or institutional goals for holding elections for certain types of office and how elections actually operate. By understanding the problem of EP elections as a "mismatch" problem, rather than as a problem that can only be solved through changing the EU's institutional structure, we can better understand how to improve European elections.

This section is divided into two parts. The first part lays out a basic model explaining how "mismatches" can develop. ${ }^{141}$ The second part discusses the fit between this model and EP elections.

1. A model of mismatch: why sub-national or super-national elections track national party preference

Ordinarily it seems safe to believe that election results are a product of voter preferences. Following Anthony Downs's classic work on parties, political scientists assume that political parties behave much like business firms, but instead of maximizing profits, they maximize vote share. ${ }^{142}$ In order to do so, they offer a program of policies that appeal to voters along the dimension over which they make their voting decision. ${ }^{143}$ In a first-past-the-post and hence two-party system, this leads to what is generally known as the "median voter theorem." If voter preferences about policy can be arrayed in a single dimension (say left to right), the two parties will position themselves in order to appeal to the median voter, as getting her vote will mean winning the election. ${ }^{144}$ In proportional representation systems, the predictions of the model become more complicated, as the optimal strategy in a multi-party election (and the number of parties that will decide to contest the election) depends on a number of factors, including the legal standard for what percentage of the vote is necessary to get a seat in Parliament, the

141. This basic model was first developed in Schleicher, City Council Elertions, supra note 31, at 422-27.

142. Id. at 428-30; see also Downs, supra note 24 , at $114-49$.

143. Downs, supra note 24 , at 139.

144. Id. at 141; Schleicher, City Council Elections, supra note 31, at 429 . There has been a great deal of research examining the effects of relaxing the extreme assumptions of the Downsian model. DenNis C. Mueler, Public Choice II: A Revised Edition of Public Choice 180 (1989). However, the basic concept of the model-that competitive pressures cause parties to propose popular policies-remains robust. See Schleicher, City Council Elections, supra note 31, at 429 n.38. 
cost of new party entry and the distribution of preferences in the electorate. ${ }^{145}$ For the purposes here, the exact strategy is not particularly important, just the idea that parties are seeking to maximize their vote share by appealing to voters and that voters reward parties that appeal to their preferences or provide good results. Just as competition leads to efficient results in markets, Downsian analysis leads us to believe that competition leads to parties proposing policies favored by voters.

What is true for a single-level national election-say a presidential race or an election for a national parliament-is not necessarily true in less wellpublicized elections at other levels of government. For instance, partisan general elections for city council in American big cities are notoriously uncompetitive. ${ }^{146}$ The vote in city council races in these cities mirrors the vote for President of the United States almost entirely. Because in most major cities one party dominates presidential races, it also dominates local races. ${ }^{147}$ This is true despite substantial evidence that voter preferences about local issues do not track preferences about national issues particularly closely. ${ }^{148}$ One can tell similar stories about statewide races for offices like Secretary of State, in which voting is completely unrelated to performance or policies. ${ }^{149}$

In a simple Downsian world, it is impossible for one party to permanently dominate elections with a huge share of the vote at any level of government. If the majority party proposes policies that are not favored by most voters, the minority party (or a new entrant) should position itself on issues at that level of government to peel off support from the majority party, reintroducing competition. ${ }^{150}$ However, in big city and a number of state elections, the process by which the minority party becomes competitive by proposing policies designed to attract the median voter does not occur. ${ }^{151}$

145. Downs, supra note 24, at 123-27; Gary W. Cox, Centripetal and Centrifugal Incentives in Electoral Systems, 34 Am. J. Pol. SCI. 903, 920-22 (1990); see generally Douglas W. Rae, The Polttical ConseQUenCis of Electoral Laws (2d ed. 1971).

146. Schleicher, City Council Elections, supra note 31, at 419-21.

147. Id. at $424,457-59$. Where national elections are close, so are local elections. For instance, Indianapolis is closely contested between the national political parties, with the vote for Democratic Presidential candidates rising over the last ten years. Tracking the national trend, Democratic candidates for both Mayor and Ciry Council won for the first time since Indianapolis established its current borders. Id. at 424, n. 24 .

148. Id. at $437-47$.

149. See infra notes $227-228$ and accompanying text.

150. See Schleicher, City Council Elections, supra note 31, at 428-29. Notably, this should be true even if preferences on national issues track preferences on local issues perfectly. As long as the minority party can position itself differently in national and local races, it should compete in a Downsian framework.

151. Recently, Kristen Badal and Jessica Trounstine have found that a large number of voters split tickets between councy elections and Presidential elections, with as many as thirty-five percent of counties having different parties win at the councy and national level. See Kristen Badal \& Jessica Trounstine, Local Versus National Partisan Representation, available at http://faculty.ucmerced.edu/jtrounstine/Local_ partisanship_August09_2.pdf. Although this seems to conflict with other available data on city elections, when examined more closely, it does not. In their regression analyses, they found that counties with large populations had far less split representation than less populated counties. Increasing the population from the smallest county in their sample to the largest county decreases the probability of split representation from sixty-eight percent to eight percent. Id. at 14 . They also found that the percentage of 
The explanation turns on voter ignorance and the content of election laws. Take big city elections. The rules governing American big city local elections, specifically campaign financing, ballot access and candidate selection in local elections, play an important role in the lack of partisan competition. First, as a matter of constitutional law, states cannot bar national parties from using their financial and organizational muscle in local elections. ${ }^{152}$ Second, state election laws guarantee ballot access to the two major parties, usually by guaranteeing ballot access on the basis of election results in gubernatorial campaigns. ${ }^{153}$ Third, election laws make it extremely difficult for those parties to establish localized identities that are different from their national party brand. They do this by limiting the ability of people to switch parties for the purposes of local election only and by requiring primary elections. If individuals make party affiliation decisions on the basis of national and not local issues, preferences about local issues do not track preferences about national issues very closely and people do not switch parties between elections, the primary electorate for local offices will not have consistent preferences on local issues. ${ }^{154}$ Primary elections across a city will thus result in standard bearers from the same party with very different preferences about local issues, making the development of a local party identity impossible. ${ }^{15 s}$

residents who lived in cities, the number of councilors per 1000 persons, and the percentage of Blacks and Latinos in the population, had strongly negative effects on split representation. Id. at 13,15 . That is, counties that look like big ciries have little split representation, and counties that are primarily rural or suburban have much more. Their data on Mayoral voting backs this up. Although they do not analyze the data this way, this is completely consistent with an argument offered by William Fischel. Fischel argued that smaller local governments were highly responsive to the interests of "home voters," who, due to the effect of local policies on the variation in their housing values, were extremely involved and active in local politics. William A. Fischel, The Homevoter Hypothesis: How Home Values Influence Local Government Taxation, School Finance, and Land Use Policies 15-16 (2001). Fischel suggests elections in localities of over 100,000 will operate like the state or federal elections, in which individuals are largely passive actors in politics. Id. at 92 . City elections are, in fact, far worse, because party information does not provide voters with the same type of information that it does in federal elections, and hence blind reliance on party information does not promote representative outcomes. See Schleicher, City Council Elections, supra note 31, at 445-52. Although other variables are quite important in determining where ticket splitting occurs-particularly education, wealth and local diversity-it is relatively clear that the dynamics of elections in big cities (and big urban counties) ensures that litcle ticket splitting occurs.

152. See Eu v. S.F. Cnty. Democratic Cent. Comm., 489 U.S. 214 (1989) (holding that California could not bar political parties from making endorsements or supporting candidates in their own primaries); Cal. Democratic Party v. Lungren, 919 F. Supp. 1397, 1399 (N.D. Cal. 1996) (holding that California could not bar parties from endorsing candidates in non-partisan elections); Schleicher, City Council Elections, supra note 31 , at 451 n. 110 .

153. See, e.g., Schleicher, City Council Elections, supra note 31, at 450 n.108.

154. See id. at $450-51$.

155. There is a growing amount of evidence that party affiliation explains either little or nothing about local politicians. Fernando Ferriera and Joe Gyourko have found that the party of the winning candidate in mayoral elections does not affect the size of local government, the allocation of local spending or crime rates, in stark contrast with federal and state election results that have dramatic effects on government policies. Fernando Ferriera \& Joseph Gyourko, Do Political Parties Matter? Evidence from U.S. Cities, 124 Q.J. ECON. 399 (2009). Using a similar methodology, Elizabeth Gerber and Daniel Hopkins found that a mayor's party affiliation does affect spending on local police and fire fighting (Republican 
Put together, these laws ensure that local voters have access to national party heuristics on their ballots but these heuristics are only slightly useful. The heuristics-i.e. the information that a local candidate is the candidate of a national party - tells local voters something about a candidate, but not much. ${ }^{156}$ However, if voters have little information about individual candidates in local races, relying on national party heuristics is a rational strategy. The reason is relatively simple: if voters know nothing about a local candidate and the only information they have is her national party membership (that is, voters know whether a candidate is a Democrat or a Republican), it is better to use this information than no information at all.

Further, local-only third parties do not enter even though there is little competition. ${ }^{157}$ The reasons for this are that they cannot gain organizational muscle and strong candidates without prying organizers and ambitious potential politicians from the major parties, something that is discouraged by the laws making party switching difficult. The use of first-past-the-post elections and the financial muscle of the two major parties make such entry even more difficult. As a result, local ballots feature national parties and not local-third party entrants. Because people choose which party they prefer on the basis of national politics, and because in most cities one party dominates national elections, local elections are extremely uncompetitive.

This result can be generalized. If voters have strong allegiances to parties at the national level and know little about individual politician behavior at another level of government, it is rational for voters to vote their national party preference in elections at the other level of government as long as there is some correlation between the party and the voter's preferences about policies for the office in question. However, where laws and/or strategic concerns mean that existing parties do not have the incentive or the ability to differentiate themselves on policy grounds at the non-national level (and/or provide barriers to entry for new parties), elections do not necessarily provide popular feedback on policies and politicians at that level. Thus, absent election laws that lead parties to provide voters with clear office-relevant heuristics, low-information campaigns featuring voters who are rational but not particularly well-informed will not produce representative results at the non-national level.

and independent mayors spend more than Democratic mayors) but not any other public policy variables. Elizaberh Gerber \& Daniel Hopkins, When Mayors Matter: Estimating the Impact of Mayoral Partisanship on City Policy, (Soc. Sci. Res. Nerwork Working Paper Series, Sept. 28, 2010), available at http://papers.ssrn. $\mathrm{com} / \mathrm{sol} 3 /$ papers.cfm?abstract_id $=1475237$. At best, political party membership tells us very little-but not nothing-about local politicians.

156. See Gerber \& Hopkins, supra note 155; Schleicher, City Council Elections, supra note 31, at 450-51.

157. See Schleicher, City Council Elertions, supra note 31, at 447, 452-54. There is only one local third party in a major American city, the Charter Party of Cincinnati, and the reasons for its existence are somewhat anomalous. Id. at 447 . 
Everything political scientists have learned about how party heuristics influence voting behavior backs up this result. It has long been known that voters have little incentive to show up at the polls-the odds of their vote mattering are negligible, while the costs of voting are real (if small). ${ }^{158}$ Further, voters have even less incentive to become informed about politics, as the costs of learning a politician's position on issues and whether those positions are good are far higher than simply showing up at the polls. ${ }^{159}$ As a result, voters know very little about politics. ${ }^{160}$

The only known solutions to this problem are political parties, and specifically political party labels. In Morris Fiorina's well-known model, voters use whatever information they pick up here or there about politicians-for instance, when they see a politician doing something on the news while flipping channels to get to Dancing With the Stars-and add it to a "running tally" of partisan preference. ${ }^{161}$ When a politician does something they like, or when they notice something is going well, they add it to their tally for the party in power, and they update their tally in a Bayesian manner. ${ }^{162}$ This running tally provides voters with a guide about how to vote. Further, as long as parties are roughly consistent in their policy positions over time, this can lead to roughly rational decisionmaking-particularly when counted across a population. ${ }^{163}$

Fiorina's model has been heavily criticized. However, these critics have attacked it for not proving enough - they argue that voters, even with party heuristics and retrospective evaluations, cannot actually assess the quality of policies particularly well. Critics claim that voters often do not know enough to attribute successes or failures to the right politicians or parties, do not assess facts in a neutral way, develop partisan affiliations without respect to issues and often punish or reward politicians for things outside of their

158. For the classic treatment of this, see Downs, supra note 24 , at $260-74$.

159. Id. at 238-76; see also Ilya Somin, Political Ignorance and the Countermajoritarian Difficulty: A New Perspective on the Central Obsession of Constitutional Theory, 89 Iow A L. Rev. 1287, 1325-26 (2004).

160. That voters know little about politics-little about the policies politicians enact, little about what expert opinion on policies is and is not enough about who is to blame-is perhaps the most basic finding of American political science. See, e.g., Robert S. Erikson, Michael B. MacKuen \& James A. Stimson, The Macro Polity xvii (2002) ("This story of unmotivated, ill-informed, and inattentive voters is as old as the first examinations of individual voters, and it is confirmed anew by every subsequent voting study. Looked upon as individuals, most Americans care little about politics and possess a level of knowledge of the details of political life that is consistent with not caring."); Somin, supra note 159 , at 1304 ("The most important point established in some five decades of political knowledge research is that the majority of American citizens lack even basic political knowledge.").

161. See Fiorina, supra note 25, at 65-83; Donald Wittman, The Myth of Democratic Failure 10 (1995) ("Voters receive a lot of 'free' information-in the news, in the mail, and in ordinary conversations.").

162. See Christopher H. Achen, Parental Socialization and Rational Party Identification, 24 POL. BeHAvIOR 151, 152-54 (2002) (creating formal Fiorina-like model with Bayesian updating).

163. Fiorina, supra note 25 , at 198-200 (". . . our analysis supports the view of the voter as a relatively rational fellow ... ."); see also Erickson, MAcKuen \& Stimson, supra note 160, at 119-35 (arguing that party identification, which is developed in a number of ways, can lead to macro-politically rational behavior); Achen, supra note 162, at 165-67 (noting that Bayesian models can explain group behavior even if they are not particularly believable with respect to individuals). 
control, like bad weather or high oil prices. ${ }^{164}$ Whether party heuristics and retrospective evaluations are effective in making otherwise rationally ignorant voters behave as if they were fully informed is not important to the claims of this Article. What is important, though, is that absent useful party heuristics, it is hard to imagine that rationally ignorant voters can make even partially informed decisions. Even Fiorina's critics would agree that party heuristics are essential if voting decisions are going to have any substantive issue-based content to them whatsoever. ${ }^{165}$

Where such heuristics are absent, voters are frequently confused. If such heuristics are available, but are not closely related to the issue being decided in the election, voters will use them anyway. ${ }^{166}$ As we will see, this helps explain what happens in EP elections.

\section{Applying the mismatch model to European Parliament elections}

Just like American local elections, EP elections do not provide voters with useful heuristics and hence are not competitive over the issues that they are intended to cover. The reasons for this are similar, although there are some differences.

As discussed above, three basic predicates for the "mismatch" model exist. First, national parties have to be guaranteed ballot access on some other type of ballot-local, or in this case, supra-national. Second, there must be some reason why those parties do not adapt to contest the election on issues related to the office in question, and why new entrants do not enter and dominate these elections. Third, voters must have little direct knowledge of the behavior of politicians in the local or supra-national body. If these three conditions are met, it is unlikely that the election will produce results that relate to the office in question.

The rules about ballot access in EP elections vary substantially from country to country and thus it is difficult to make general statements about them. However, they do have several things in common. First, member states choose the election law system used in EP elections, giving incumbent

164. See, e.g., Donald Green, Bradley Palmquist \& Eric Shickler, Partisan Hearts and MiNDs 8-14, 89-139 (2002) (arguing that party identification is primarily social and evidence of macroresponsiveness of voting to events is flawed.); Larry Bartels, Beyond the Running Tally: Partisan Bias in Political Perceptions, 24 Pol. Beravior 117, 120 (2002) (stating that Democrats and Republicans understand political phenomena differently, biasing running tally decisionmaking); Somin, supra note 159 , at 1325-28 (stating that retrospective voting models are flawed because of lack of voter knowledge about whom to blame for policy failures); Ilya Somin \& Neal Devins, Can We Make the Constitution More Democratic?, 55 Drake L. Rev. 971 (2007); Justin Wolfers, Are Voters Rational? Evidence From Gubernatorial Elections (Jan. 30, 2007), http://bpp.wharton.upenn.edu/jwolfers/Papers/Voterrationality(latest).pdf (arguing that voters are only partially capable of sorting out responsibility for causes of economic growth).

165. See, e.g., Somin \& Devins, supra note 164, at 979 ("Shortcuts can sometimes partially alleviate the problem of rational ignorance. But they are not a complete solution for it . . .").

166. Further, the development of such long-term associations inhibits the ability of local-only third party entrants. If voters make associations on the basis of retrospective evaluation, new entrants without a record will face an uphill climb. 
parties an advantage. ${ }^{67}$ Second, national parties are often given large financial subsidies by national governments. ${ }^{168}$ Most importantly, national parties are in a strong institutional position resulting from domestic elections-the money raised, their membership-and this makes it easy to get on the EP ballot. In the last EP election, the major national parties in each country contested the election. ${ }^{169}$

The presence of national parties on the EP ballot, on its own, does not ensure that these "brands" will mean the same thing to voters in EP elections as they do in national elections. A party theoretically could attempt to stake out a separate identity for national elections and for EP elections. However, all evidence suggests that parties do not do that. Whereas the primary reason why American parties do not stake out differentiated local identities was legal; in EP elections, it seems that the issue is strategic. ${ }^{170}$

National political parties that care more about national politics than about the EU may get more benefit out of fighting an EP election on domestic grounds than on European ones. By campaigning exclusively on national issues parties can claim victory in an important symbolic national election, a "marker" of things to come. ${ }^{171}$ Second, campaigning on European issues can carry a substantial cost-if the party is divided on some European issue, fighting a campaign on European issues could create fissures that could last until the next general national election. ${ }^{172}$ This famously happened in the British EP campaign of 1989, where EP campaigning caused a rift between pro and anti-EU forces in the Conservative Party and

167. See Jurij Toplak, European Parliament Elections and the Uniform Election Procedure, 15-16, http:// www.enelsyn.gr/papers/w3/Paper\%20by\%20Jurij\%20Toplak.pdf (last visited Nov. 20, 2010).

168. See Ernest A. Chaples, Developments in Australian Election Finance, in Comparative Polrtical Finance Among the Democracies 29-40 (Herbert E. Alexander \& Rei Shiratori eds., 1994); Pilar del Castillo, Problems in Spanish Party Financing, in Comparative Political Finance Among the DemocRACies, supra, at 97-104; Gullan M. Gidlund, Regulation of Party Finance in Sweden, in Comparative Poutical Finance Among the Democracies, supra, at 105-14; Ruud A. Koole, Dutch Political Parties: Money and the Message, in Comparative Political. Finance Among the Democracies, supra, at 115-31; Christine Landfried, Political Finance in West Germany, in Comparative Political Finance Among the Democracies, supra, at 133-44.

169. Compare Results of the 2009 European Elections, supra note 102 (listing 2009 EP election results by country by party), with PARTIES AND Elections IN EuROPE, http://www.parties-and-elections.de/ countries.html (last visited Nov. 6, 2010) (showing last parliamentary election results in each European country).

170. These strategic concerns also likely affect local elections in the United States. Political parties may be afraid to take stances on local issues for fear of harming the narional coalition. For instance, taking a stance on some controversial education issues (e.g., the teaching of creationism) might cause harm to unity inside major political parties that otherwise would not have had to take a stance on these issues.

171. Oppenhuis et al., supra note 96 , at 288-89. This explains a major difference between EP elections and big city local elections. In local elections, most candidates talk about local policies, even if national politics is going to dominate voter decisionmaking. In EP elections, parties do not mention European issues, and the difference is due to the respective candidates' desire. Local politicians--particularly given the candidate-centric nature of campaigns in the United Stares--want to take credit for a local mandate, as it will give them power in a local legislature. EP campaigns are waged by national parties, and they want credit for a national political mandate.

172. See id. at 290-95. 
helped bring down the Thatcher government. ${ }^{173}$ Further, in countries where there are strong legal limitations on the ability of parties to engage in campaigning activities, EP elections give parties a chance to compete for public affection on national issues. ${ }^{174}$ There is substantial empirical evidence that political parties do not create separate platforms in EP elections for these reasons. ${ }^{175}$

Moreover, it is unclear whether parties could develop separate EP identities even if they wanted to. Where parties are able to develop identities that are separate from their national identity-for instance, Southern Democrats for most of the twentieth century - they usually are able to do so over the course a series of elections in which they are able to win and exercise some power. This allows voters to develop locally-based running tallies based on performance in office. EP elections happen only once every five years and are the only type of pan-European election. Also, no one domestic party controls the EP, making running tallies based on retrospective evaluations of party performance difficult to come by. Domestic parties do not have the tools for differentiating themselves at the European level.

EP elections do not have the high barriers to entry for pan-European or issue specific parties that exist in American local elections. ${ }^{176}$ The absence of these limits is why we see the flourishing of small parties in EP elections, ranging from xenophobes to groups in favor of internet piracy. ${ }^{177}$ However, these small parties still lack the track record of service through which voters can develop a running tally and hence positive associations. ${ }^{178}$ Thus, there are limits to the degree to which new EP-election-only-parties can succeed.

EP voter behavior fits the model. Most voters know little about where MEPs or Euro-parties stand or about their performance in office. ${ }^{179}$ Given this, and given the existence of their national parties on the ballot, voters rely on their existing running tallies about domestic issues. Again, in the absence of other information, this is rational-a voter who prefers Labour in

173. See Mark Franklin \& John Curtice, Britain: Opening Pandora's Box, in Choosing Europe? The European Electorate and National. Politics in the Face Of UNion, supra note 71, at 94-95.

174. See Navraj Singh Ghaleigh, The UK's Political Parties, Elections and Referendums Act 2000, in Party Funding and Campaign Financing in Comparative Perspective, supra note 67, at 47 (noting time limits on Britain's campaign expenditure limit).

175. See Mark Franklin et al., Conclusions: The Electoral Connection and the Democratic Deficit, in CHOOsing Europe? The European Electorate and National. Politics in the Face of Union, supra note 71 , at $370-71$.

176. EP elections are required to use either proportional representation or single-transferable vote, both of which create lower barriets to entry than does a first-past-the-post single-member-district system.

177. See supra note 2 and accompanying text.

178. By their very nature, small parties do not govern, in the EP or elsewhere. As the EP does not provide opportunities to govern either, voters do not have the ability to develop running tallies based on their performance.

179. "[T] $[$ he media, the public and even most domestic political elites are unaware of the new politics in Brussels. For example, few TV news editors or national MPs, let alone private citizens, realize that political parties dominate politics in the European Parliament ..." Hix, WhAT's W 3 , at 137 . 
Britain is more likely to prefer the policies of Party of European Socialists in the EP than those of other parties. However, voting based on domestic preferences will mean that things that do not (and could not) matter to a voter's preferences about EU policy will be reflected in the vote. For instance, the EP elections in Britain in 2004 were largely treated by voters as a referendum on Tony Blair's support for the war in Iraq, leading to losses for the Party of European Socialists in the EP, despite the fact that most members of that party opposed the war (and despite the fact that the EP had no power at all over the war). ${ }^{180}$

Because domestic parties are on the ballot and because voters have little other information, voters use their preferences about domestic parties in EP elections, even though the connection between how voters feel about domestic issues and how they feel about what policies should predominate in the EU is unclear. ${ }^{181}$

There is one more wrinkle. For some sets of preferences, it is possible that EP elections would look the same even if voters were very well informed. If voters care much more about national politics, they might value the opportunity to use EP elections as a way of sending a message to domestic politicians more than they care about getting policies out of the EP that they like. However, it is unclear what public purpose is achieved by using public funds to allow voters to express functionally meaningless preferences. Using a non-binding poll about domestic politics as a basis for choosing officials for a supra-national legislature is simply bizarre. ${ }^{182}$

More importantly, whether voters use EP elections to comment on domestic politics because they are under-informed, or because they really like sending messages to domestic governments in different ways, EP elections

180. See, e.g., Battered Blair pusbes domestic agenda, Toronto STAR (Can.), Sep. 27, 2004, at A13; John Daniszewski \& Tracy Wilkinson, Anti-EU Factions Gain in Europe Polls, L.A. Times, June 15, 2004, at A3; James Kirkup, Blair Faces His Longest Week as the Numbers Add Up Nicely for Brown, Scotsman (U.K.), July 12, 2004, at 8; Andrew Rawnsley, How the Bloody Anarchy of Iraq Broke the Spirit of Tony Blair, Observer (U.K.), Feb. 28, 2010, at 32; see also Blair's Paradox, ECONOMIST, June 17, 2004, (noting that Blair himself viewed this as the reason for Labour's poor performance in the EP elections). The EU obviously has no control over the United Kingdom's military decisions. To the extent that any EU body would have influence over this question, it would be through the Common Foreign and Security Policy, which seeks to coordinate Member State foreign policies, and the European Security and Defense Policy, neither of which the EP has any power over. See Denis Chaibi, The Foreign Policy Thread in the European Labyrinth, 19 CONN. J. INT'L L. 359, 363, 374-80 (2004).

181. Even if there is a high correlation between preferences about domestic policies and EU policiesand there is likely a substantial correlation-the mismatch problem creates a lack of democratic accountability. First, there is some difference, as purely domestic events, like the UK Parliaments expense scandal, affect the results. Further, even if candidates are chosen for their preferences on certain issues, if voters use domestic and not international preferences, there is no retrospective accountability. MEPs may be selected in part based on preferences that are common across domestic and EU issues, but there is no punishment if they do not vote that way.

182. The perversion, it should be noted, is institutional, not individual. For individuals, using EU elections to comment on domestic politics is perfectly rational. But there is no reason power should be vested in the EP if its membership is chosen merely on the basis of messages voters want to send to their domestic parliaments. 
do not serve the goals EU leaders set out for them. Further, it is clear that the system of elections-the election laws and their interaction with the state of party competition inside countries-either promotes this failure or, at least, does nothing to ensure that EP elections serve their intended goal. That is, the election system and the constitutional system do not promote the same ends. There is a mismatch.

The question is whether this dynamic can be changed. The next section will argue that it can.

\section{B. An election law solution to the problem of mismatch in European Parliament elections}

As noted above, election law rules are never purely neutral and, instead, structure the types of competition in elections. The clearest examples of how election law can be used to structure politics comes from efforts to write new constitutions for emerging democracies to deal with the problem of group representation in ethnically divided societies. For at least the last forty years, political scientists have been dreaming up new and more complex constitutional and institutional systems designed to reduce tensions and aid democratic development. ${ }^{183}$ Electoral systems are considered by these scholars to be "by far the most powerful lever of constitutional engineering for accommodation and harmony in severely divided societies ...."184 As such, these political scientists and political reformers propose different types of "electoral engineering," different voting systems designed to alleviate the problems faced by new democracies. ${ }^{185}$ Similar forms of electoral engineering could be used to solve the problems of EP elections.

Current EP election rules actually track one popular form of electoral engineering popular in many developing countries, "consociationalism," which, by using proportional representation and creating multiple veto points, ensures that policy cannot be made without widespread agreement. This conflicts with the goal of having the EP as a direct popular check on the Commission and Council. Using the tools of a rival school of electoral engineering, "centripetalism," EU officials could create EP elections that allow the EP to serve its institutional purpose.

After reviewing these two mechanisms of how election laws can be engineered to achieve certain types of results, I will lay out a concrete proposal for reforming EP elections: a requirement that, in order to receive any MEPs from any country, a party must receive a certain percentage of the vote in

183. For a brief history of this scholarship, see Benjamin ReILy, Democracy in Divided Societies: Electoral Engineering for Conflict Management 12 (2001). Giovanni Sartori is generally considered to have pushed the creation of this subfield. See generally Giovanni Sartori, Political Development and Political Engineering, 17 Pub. Pol'y 261 (1968).

184. Donald Horowitz, A Democratic South Africa? Constitutional Engineering in a Divided Society 163 (1991).

185. See ReILY, supra note 183 , at 12. 
more than seven European countries. This would force Euro-parties onto the ballot, thereby giving rationally ignorant European voters some means by which to connect what MEPs do to their voting decisions. It would also encourage pan-European campaigning.

\section{Electoral engineering and institutional design}

The most famous efforts at electoral engineering are European in origin. Arend Lijphart used the term "consociationalism" to describe the political systems developed in parts of Europe as a way beyond the social cleavages occasioned by the end of World War II. ${ }^{186}$ Four political features characterize consociational democracy: proportional representation ("PR") of different groups in the distribution of legislative seats, grand coalition governments in which all significant groups are represented; federalism or similar devices for dividing authority for local policies along geographic or ethnic lines; and a power of veto over key decisions by minority groups. ${ }^{187}$ The idea is that by giving each ethnic or social group in a country a say in government, some degree of veto power, and control over their own affairs, groups with generally incompatible goals and desires will buy into a government that protects their interests. The key role is played by elites, who represent these incompatible groups but are assumed to be able to reach consensus inside grand coalitional governments. ${ }^{188}$

It has been argued that the EU, like a number of European nations, effectively uses a consociational model. ${ }^{189}$ Moravcsik's argument that the EU governs by consensus, with each major group or country able to effectively veto EU policy, is basically a claim that the EU is a consociational system. ${ }^{190}$ The EP incorporates many consociational elements-for instance, control over committees is shared among all the parties. ${ }^{191}$ Critics of consociationalism make points similar to Simon Hix's criticism of the EU's brand of democracy. First, consociational arrangements have been criticized for creating policy deadlock, as consensus is required to make policy. ${ }^{192}$ Second, elections under consociational arrangements create centrifugal forces, in which parties try to maximize their own group representation by emphasizing their differences with the rest of the government and country. ${ }^{193}$ Third, and most relevantly for this study, consociational arrangements devalue representation on

186. See generally Arend Lijphart, Democracy in Plural Societies (1977).

187. See id. at 25-44; see also Donald Horowitz, Ethnic Groups in Confuct 569-70 (2d ed. 1985); Matthijs Bogaards, Electoral Choices for Divided Societies: Multi-Ethnic Parties and Constituency Pooling in Africa, 41(3) Commonwealth \& Comp. Pol. 59 (2003).

188. See Benjamin Reilly, Democracy and Diversity: Poljtical Engineering in the Asia-PaCIFIC $81,88(2006)$.

189. See Matthijs Bogaards, The Consociational Analogy of the EU: A Rejoinder to Crepaz with a Comment on Kaiser, 3 Euro. Union. POL. 501 (2002).

190. See supra notes $123-128$ and accompanying text.

191. See HIX, What's Wrong, supra note 3, at 138-45.

192. ReILly, supra note 188 , at 81 .

193. See Horowitz, supra note 184 , at $172-74$. 
the basis of ideological positions in favor of representation on the basis of group or nationality. Under consociational arrangements, the people as a whole do not ever really have the opportunity to express clear views on national policy matters. ${ }^{194}$

Determining whether the EU as a whole is a consociational system (or whether that is a good thing) is beyond the scope of this Article. However, the EP was not intended to be consociational - it was supposed to provide clear guidance about the beliefs of European voters on EU policies. The question is whether electoral engineering can provide a tool for making the EP achieve that goal.

Other experts have pushed an alternative theory of electoral engineering in divided societies-centripetalism. ${ }^{195}$ Donald Horowitz notes that centripetalism's "principal tool is . . the provision of incentives, usually electoral incentives, that accord an advantage to ethnically based parties that are willing to appeal, at the margin and usually through coalition partners of other ethnic groups, to voters other than their own." 196 Rather than divide power among ethnic parties and strive for general consensus, which can solidify the primacy of ethnic identities in politics, centripetalists seek to give an advantage to groups that move beyond ethnic or territorial boundaries and generate national majoritarian electoral competition along some other axis.

One policy suggested by centripetalists is a "distribution requirement," or withholding any representation from candidates or parties that fail to receive a certain percentage of the vote in a majority of provinces. ${ }^{197}$ Distribution requirements are used in Nigeria, where truly national presidential elections have been held since 1979 (albeit ones that have on several occasions been overturned by military coups). ${ }^{198}$ In Nigerian elections preceding the Biafran War (Nigeria's civil war), voting was divided rather neatly by party and ethnic group, with each of the nation's three major ethnic groups-the Hausa-Fulani, the Yoruba and the Igbo-controlling different territorial areas and represented by different parties. ${ }^{199}$ The Biafran War resulted from this ethnic-geographic divide being the salient division in Nigerian politics. After the war, Nigeria wanted to create a system that disincentivized ethnic block voting. ${ }^{200}$ In the election code introduced in 1979 , presidential candidates were not only required to receive a plurality of

194. See ReILY, supra note 188 , at $79-80$.

195. See, e.g., id. at 83-91; Bogaards, supra note 187, at 65 . The term was coined by Timothy Sisk. See Timothy D. Sisk, Democratization in South Africa: The Elusive Social Contract 17-55 (1995).

196. Donald L. Horowitz, Conciliatory Institutions and Constitutional Processes in Post-Conflict States, 49 WM. \& MARY L. Rev. 1213, 1217 (2008).

197. See Bogaards, supra note 187 , at $64-68,70-71$, for a full discussion of the idea.

198. Larry Diamond, Nigeria: The Uncivic Society and the Descent into Praetorianism, in Pourrics IN DEveloping Countries: Comparing Experiences with Democracy 417, 469 (Latry Diamond et al. eds., 2d ed. 1995).

199. Id. at 466.

200. Bogaards, supra note 187 , at $70-73$. 
the votes but also needed to get twenty-five percent of the vote in at least two-thirds of the federated states. ${ }^{201}$ The first election under the system was, at least by Nigerian standards, a success-the winning candidate, Shehu Shagari, either met or came extremely close to meeting the regional requirements (and was declared to have met the requirements) running what was the country's first truly national campaign. ${ }^{202}$ Although Nigerian presidential elections since 1979 have had a large number of other problems, they have largely consisted of competitions between candidates who have run national campaigns, not targeted local ones. ${ }^{203}$

Two other countries use distribution requirements. Indonesia has a tworound majority run-off system, but for a candidate to be elected in the first round, she must not only poll an absolute majority of votes cast but also meet a distribution requirement of twenty percent of the vote in at least half of the provinces. ${ }^{204}$ In Kenya, presidential candidates must receive at least twenty-five percent of the vote in a minimum of five out of eight provinces. $^{205}$ (Admittedly, it has been less than a success there-regional and ethnic conflict broke out after the last Kenyan election despite the distributional requirement. ${ }^{206}$ )

Regional requirements come in weaker versions as well. A large number of countries have requirements that parties are registered and have membership in a number of states in order to qualify for representation. ${ }^{207}$ Romania, an $\mathrm{EU}$ member state, has quite extensive registration requirements. In order to register with the Court of Justice and to appear on the parliamentary ballot, a party must gather at least 700 signatures in eighteen of the country's forty-two regions and must run candidates in twenty-one regions. ${ }^{208}$

201. HoRowitz, supra nore 184 , at 184 .

202. See Bogaards, supra note 187 , at $70-71$.

203. See id. at 70; Horowitz, supra note 184, at 184-87; see also Peter M. Lewis, Endgame in Nigeria? The Politics of a Failed Democratic Transition, 93 African Afralrs 327 (1994) (noting that the 1989 election in particular "suggested an historic merger of northern and southern populist interests, superseding the ethnic faultlines which have traditionally structured Nigetian electoral politics").

204. Indonesia: Continuity, Deals and Consensus, ACE Electoral Knowledge Project Encrclopedia, http://aceproject.org/ace-en/topics/es/esy/esy_id (last visited Nov. 6, 2010).

205. See Constitution, Chapter 2. Sec. 5(3f) 1998 (2001) (Kenya). For a discussion of the regional requirements, see Electoral Poljtics in KenYa 41-42 (Ludeki Chweya ed., 2002).

206. See European Union Election Observation Mission, Kenya-Final Report General Elections 27 December 2007 (April 3, 2008), http://ec.europa.eu/external_relations/human_rights/election_observation/ kenya_2007/final_report_en.pdf.

207. Ten countries have regional distribution requirements for political parties running in national elections for the lower representative chamber, and three countries-India, Nigeria, and Romaniahave regional distribution requirements for political parties running in national elections for the upper representative chamber. For example, in Turkey, where there are eighty-one provinces, a qualifying party has to be fully organized in at least half of the provinces and one-third of the districts within these provinces. The ACE Electoral Knowledge Network, Comparative Data: What are the Registration Requirements for Political Parties Running for National Elections (Chamber 1)?, http://aceproject.org/epic-en/CDMap ?question $=$ pc001 (last visited Nov. 6, 2010).

208. See Vera Stojarová, Jakub Šedo, Lubomír Kopecek \& Roman Chytilek, Political Parties in Central and Eastern Europe: In Search of Consolidation, Central and Eastern Europe Regional Report, 62-63 (2007), http://www.idea.int/publications/pp_c_and_e_europe/upload/Regional_Report_CEE.pdf. 
There is even a regional requirement in the EU's law on Euro-parties. In order to qualify for an EU grant, a party on the European level must "be represented, in at least one quarter of Member States, by [MEPs] or in the national Parliaments or regional Parliaments or in the regional assemblies, or it must have received, in at least one quarter of the Member States, at least three per cent of the votes cast in each of those Member States at the most recent European Parliament elections."209 These requirements apply to the domestic parties that join together to support a single Euro-party. Eleven separate parties received EU funding by meeting these targets in $2005 .{ }^{210}$

\section{Using distribution requirements to reduce the mismatch problem in European Parliament elections}

The basic logic of Nigeria's presidential voting system, and the Europarty funding system, could be applied to EP elections. EP elections all use proportional representation or single transferable vote. ${ }^{211}$ Proportional representation systems usually have a "threshold" requirement. ${ }^{212} \mathrm{~A}$ party must receive a certain percentage of the vote in order to receive any seats. For instance, in German elections, a party must receive at least five percent of the vote to receive any representation in the national parliament, the Bundestag. ${ }^{213}$

The EU could require parties to meet a Europe-wide threshold as well as one in any given country. ${ }^{214}$ For instance, using the existing rules for funding Euro-parties, the EU could pass legislation that stated that, in order to receive any seats from any country in the EP, a party must receive directly at least three percent of the votes cast in a quarter of the member states. The Euro-parties could not, however, count votes for domestic parties that are allied together towards meeting this requirement. The Labour Party would

209. Commission Regulation 2004/2003, On the Regulations Governing Political Parties at European Level and the Rules Regarding Their Funding, 2003 O.J. (L 297) 1.

210. The amounts and the recipients of money under Commission Regulation 2004/2003 for 2005 are available at http://www.europarl.europa.eu/tenders/subventions_2005.htm (last visited Nov. 6, 2010).

211. See Toplak, supra note 167 , at 16 . Under a single transferrable vote system, voters rank order candidates, and the candidate with the lowest number of first-place votes gets eliminated, and all the votes that went to her are then "transferred" to the candidate ranked second on the voters ballot. This process continues until there is a single winner (if there is more than one seat in the district, then the process becomes a bit more complicated, as votes from candidates who have hit the necessary amount also have to be transferred). Daniel R. Ortiz, Note: Alternative Voting Systems as Remedies for Unlawful At-Large Systems, 92 Yale L.J. 144, 150 \& n.30 (1982).

212. See Michael Gallagher, Comparing Proportional Representation Electoral Systems: Quotas, Thresbolds, Paradoxes and Majorities, 22 Brit. J. Pol. SCI. 469, 485 (1992).

213. Steven G. Calabresi, The Virtues of Presidential Government: Why Professor Ackerman is Wrong to Prefer the German to the U.S. Constitution, 18 Const. Comment. S1, 62 (2001).

214. I have only seen one reference to a similar idea. Mark Franklin, Cees van der Eijk and Michael Marsh, although supportive of pan-European ideological competition, dismiss the possibility of such a legal requirement as not "practical." Franklin et al., supra note 175 , at 379 . They do not explain why they think it is not practical, though. 
not receive any EP seats in the UK unless it also won-under its own banner-three percent of the vote in eight European countries. ${ }^{215}$

All major European parties are purely domestic. None would be able to win any percentage of the vote in another country. As the domestic parties would be unable to win EP seats on their own, they would be forced to put the Euro-party names on the ballot. Voters in the UK, thus, would not see a ballot consisting of candidates from Labour, the Conservatives, the Liberal Democrats, the United Kingdom Independence Party and other domestic parties, but would instead see the Euro-parties: the Party of European Socialists, the European People's Party, the Alliance of Liberals and Democrats for Europe and the Europe of Freedom and Democracy Group (and four others as well).

The immediate effect of this regulation on who runs for a seat as an MEP would be small. Nothing about the rule would require national political parties to lose the power to appoint candidates, nor would it reduce the influence of domestic parties inside the Euro-parties. ${ }^{216}$ Efforts to enhance the power of the Euro-parties have traditionally focused on their funding and their organizational independence from domestic parties and from legislative groups in the EP. ${ }^{217}$ However, these are the wrong tools. Rather than focusing on the institutional apparatuses of parties and candidates, the EU should make the names of Euro-parties available to voters on EP ballots. Instead of trying to change the behavior of elite politicians, this change would directly affect what voters know. And lack of voter knowledge is the main problem of EP elections.

Putting the Euro-parties on the ballot would have the effect of giving voters a more accurate heuristic about MEP voting practices. They could track the voting behavior of both members of the Euro-parties from their country, and from others, in the running tally style. The ability to use running tally decision making should help alleviate the problem caused by the fact that voters lack much direct information about EP policies. After all, many voters at all levels of government do not closely follow government policymaking: parties and party labels give them the tools to render whatever observations they do have into useful votes. Parties that accurately

215. If this rule was in place in 2009 and all current Euro-party groups got the same vote as their constituent domestic parties received in 2009, each of the eight Euro-party groups would have received representation. The European Conservatives and Reformists group is the only party that would have come close to missing the mark, having received over three percent in exactly eight countries. See Results of the 2009 European Elections, supra note 102 (examining results by country and party).

216. Ernest Young argues that one of the main protections of the powers of Member States is the absence of representative democracy in the EU. See Young, supra note 7, at 1705 . The lack of programmatic parties, he claims, makes the EU less legitimate and hence less likely to take power from Member States. This may be true, although it is equally true of other things that would contribute to the EU's legitimacy, like conducting policy well. However, some degree of competition for legitimacy is built into the EU system, and this reform-if it worked-would only introduce that type of competition to the level envisioned by the EU's existing treaties.

217. See generally Day \& Shaw, supra note 67, at 295-320. 
reflect the choices made by EP politicians could help voters overcome their lack of knowledge about politics.

However, as the salience of EP issues is lower than domestic issues, the effect of having responsive parties at the EP might be small, particularly at first. Voters may well just equate the Euro-party with its domestic partner. However, this is unlikely to last over time. As voters would be able to make connections between Euro-party performance and their voting decisions, at least some voters would develop opinions about them-independent of their opinions about the domestic performance of their partner party. The Europarties themselves would have incentives to build their brand names. Whenever their domestic partners were unpopular, they could turn to pan-European appeals in order to rally support.

The basic models we use to understand voting decision-like Fiorina's running tally model-suggest that the existence of a heuristic on the ballot will lead to its use by voters. Further, even if the effect is small and only a few voters develop preferences about Euro-parties that are distinct from their preferences about national parties, this would still be significant. Party control of the EP is usually quite close, and even a small Europe-wide shift could change that balance in overall EP elections. ${ }^{218}$

Further, there is at least some evidence that voters can successfully track two separate party systems. For instance, cities in both British Columbia and Quebec, Canada, have elections with entirely different parties than exist at the national or even the provincial level. In Vancouver, the Non-Partisan Alliance contests elections against the Vision Vancouver and the Committee For Progressive Electors. ${ }^{219}$ In Montreal, Vision Montreal, Union Montreal and Projet Montreal compete. ${ }^{220}$ These parties have no national or provincial analogue (although there are ties between some local parties and provincial and national parties), but nevertheless create intense local partisan competition. ${ }^{221}$

Having Euro-parties on the ballot would also encourage campaigning on EU issues. Domestic parties that thought they could be successful in EP elections by bringing up European issues, but were worried that doing so might prove harmful later in domestic elections, would face changed incentives. Because the blame-or the credit-would go to the parties running and not necessarily to the domestic party, parties would have to worry less about "blowback" in later domestic elections. Similarly, it would reduce

218. No party has ever had fifty percent of the seats in EP necessary to organize it. Nor has any combination of two parties aside from the two major parties, the PES and EPP. See Democratic PolitICS, supra note 4 , at 24-26.

219. Justine Hunter, Vision Prevails in Landslide Victory, Globe And MaIL (Can.), Nov. 17, 2008, at S2; Greg Joyce, Voters Heading to Polls in B.C. Municipal Elections, Portage Daily Graphic (Can.), Nov. 18, 2005, at 9; See Why Vancouver Works, MaClean's (Can.), July 27, 2009, at 2.

220. See generally Martin Patriquin, Montreal is a Disaster, Maclean's (Can.), Nov. 9, 2009.

221. Id. 
domestic party incentives to campaign on domestic issues, as the credit (or blame) would not run to them for winning or losing.

The change would likely limit beggar-thy-neighbor campaigning. There is currently no check on the desirability of making nationalistic claims in EP elections, and parties sometimes claim that they will choose policies that will disproportionately help their home country (even though left-right politics determines MEPs voting patterns far more than nationality). Parties can make these claims because they are not held accountable for them in other countries. If the Euro-parties appeared on the ballot, parties that run exclusively on their ability to get more money for one country theoretically could be held accountable by the press or other parties in other countries. Candidates in the United States often use famous figures from other states in their campaigns (e.g. Republicans from the South using Nancy Pelosi in their campaign ads). Although this effect does not eliminate claims that candidates will bring home pork, it certainly limits more aggressive versions of regional campaigning. A distribution requirement may serve the same function in EP elections.

Finally, the proposal would also limit the ability of otherwise informed voters to use the EP ballot to comment on domestic politics. ${ }^{222} \mathrm{~A}$ vote against the Party of European Socialists would not be read as clearly as a comment on domestic politics as, say, a vote against the Labour Party. The diminished utility of the EP vote as a method of commenting on domestic politics would lead to the diminished use of it among informed voters. This reform would thus make EU issues more prominent in EP voting decisions among both informed and uninformed voters.

The proposal would have costs, as well. All thresholds, like the rule that a party must receive five percent of the vote to receive any seats in the Bundestag in Germany, serve to exclude certain groups with real support from winning seats. This rule would serve to exclude holders of certain viewpoints from the EP, in this case ideas that are not pan-European. Further, it would result in a certain number of wasted votes. ${ }^{223}$ If the rule proves too strict and excludes too many groups with real support, this result

222. One of the major critiques of the Fiorina model is that political party identification is more likely to be determined by tribal-like personal identification rather than by assessment of possible policy outcomes. See GreEN ET AL., supra note 164, at 8-11. To the extent that this is correct, the suggested reform will be particularly attractive as there will be no group on the ballot with which to identify, voters will have to make an assessment of policies in order to determine whom to vote for and not merely rely on their group identification.

223. In an important contribution to this discussion, Richard Pildes has called for constitutional arrangements with time limits. Richard $\mathrm{H}$. Pildes, Ethnic Identity and Democratic Institutions: A Dynamic Perspective, in Constitutional Design for Divided Societies: Integration or Accommodation? 173, 185-88 (Sujit Choudhry ed., 2008). He argues that consociational arrangements may be important at the outset of new democracies, but that a move to centripetal laws is often good. He suggests, following the example of the South African Constiturion, that centripetal arrangements be given a time limit to phase out, allowing their replacement (and avoiding their calcification) with policies designed to create post-ethnic societies. Id. A similar idea might be useful in EP elections, although in the opposite direction. 
could be mitigated by making the rule temporary, lasting only a few election cycles until pan-European parties are developed, or by reducing the threshold for the number of states in which a party needs to win seats.

However it is implemented, a distribution requirement would have the effect of making EP elections serve their intended purpose in the EU's institurional structure. That is, they would give voters the ability to use EP elections to provide feedback about EU issues. Notably, it would do so without undermining or changing the basic structure of the EU. Member states would still have representation in the Council, and that would still be done on the basis of domestic election results, which would remain unaffected by this legislative change. If the reform worked, and voters were able to separate their commitment to a domestic party from their beliefs about what the EU should do, the EU's current system of the separation of powers could be preserved. Even if it did not work as intended, it would still serve to limit beggar-thy-neighbor campaigning in EP elections.

\section{Conclusion: The Mismatch Problem in America and Europe}

The problems of EP elections are not unique. They look a great deal like the problems of American local elections, only in reverse. ${ }^{224}$ Whereas in big American cities, national party preference determines the vote for local office with little reference to local performance or conditions, in EP elections, national party preference determines the vote for a supranational legislature with little reference to the performance of politicians at the supranational level. Both American local governments and the EP fail to reflect the preferences of voters about the issues these entities decide.

Further, the goals of having elections for these offices and the repeated practices of voters are in tension. ${ }^{225}$ Just as EU leaders decided to have direct

224. Local elections in Europe are generally second-order, although less so than EP elections. See Anthony Heath, Iain McLean, Bridget Taylor \& John Curtice, Between First and Second Order: A Comparison of Voting Behaviour in European and Local Elections in Britain, 35 Eur. J. POL. Res. 389 (1999).

225. In an interesting new essay, Paul Edelman argues that the "institutional dimension" of electoral design is extremely understudied. See Paul H. Edelman, 'And the Oscar goes to. .' The Academy Awards and the Institutional Dimension of Election Design (Vand. L. \& Econ. Res., Working Paper No. 9-23, 2009), available at http://papers.ssrn.com/sol3/papers.cfm?abstract_id=1456529. Edelman argues "that elections are about more than just preference aggregation. Elections are organized by institutions, and those institutions may have interests that are distinct from the preferences of voters." Instead, vote counting systems can achieve specific institutional goals, like higher ratings for the Oscars. Further, his analysis of vote counting systems in democracies shows that the methodology for tabulating preferences will necessarily involve different institutional goals and theoretical ideas about what constitutes a democratic result. Rather than thinking of particular election methods-proportional representation, first-past-thepost, instant run-off, etc.-as better or worse than others, they should be analyzed by how well they achieve specific institurional goals, of which accurate tallying of pre-existing preferences is important, but by no means the only value. Edelman's argument has much in common with Samuel Issacharoffs brilliant work on election law in transitional constitutional orders. See generally Samuel Issacharoff, Fragile Democracies, 120 HARv. L. Rev. 1405 (2007) (examining how election law rules can, in different institutional settings, create different incentives, and why democracies at different levels of security might make different decisions on rules governing elections). This Article argues that EP vote counting system should 
elections for EP in order to have direct voter comment on EU policies, American states presumably decided to hold local elections in order to ensure that cities are governed according to the preferences of local people about local policies. In both cases, the fact that national party preference determines voting results undermines these constitutional intentions.

The clear lesson from both American local elections and EP elections is that a constitutional or institutional structure that calls for elections for a type of public office will not necessarily result in the type of political competition that the constitutional framers wanted. This is largely a product of rational voter ignorance. Voters are asked to provide their opinions on how a body should be governed, but they individually have little incentive to develop these opinions. Absent the proper tools to overcome their rational ignorance along the proper dimensions, allocations of power to elected entities often will not achieve constitutional ends.

In modern elections, the most relevant tool voters have for overcoming their ignorance of politics is the heuristic provided by a political party. In national elections, this works well. When people vote for a unitary national parliament or a national president, political parties provide clear signals about the policy proclivities and past responsibility for policies. Further, in these major elections, voters pay sufficient attention-or at least some voters, although certainly not all-and can develop independent preferences about candidates and their policy proposals. ${ }^{226}$

In other types of elections, though, the party heuristic is effectively the only tool voters have, and it is not necessarily a particularly useful one. If political party competition does not produce a relevant heuristic along the same dimension as the issues the official or legislative body decides, or the goals the framers had for the body, the goals of the constitutional system will likely not be met. That is, there will be a "mismatch" between constitutional or institutional goals and electoral reality.

Both American local elections and EP elections fall into the mismatch trap. But they are not the only examples. For instance, Heather Gerken has shown that a similar dynamic occurs in elections for secretary of state and other officials at the state and local level. ${ }^{227}$ In most states and many localities, the officials that decide how to run elections-which voting machines to use, where to locate voting booths, how to organize a recount, etc.-are elected themselves, but the same combination of voter ignorance and the availability of party heuristics that determines the results in local elections makes decisionmaking in these elections purely partisan. ${ }^{228}$ Voters, bereft of

attempt to fit the institutional interests expressed in the treaties establishing the EU and its separation of powers.

226. This is why some big city mayoral general elections are competitive. See Schleicher, City Council Elections, supra note 31 , at $445-47$.

227. See Heather Gerken, The Democracy Index 15-26 (2009).

228. Id. 
information about the actual performance of secretaries of state as election administrators, make decisions exclusively on the basis of which official is most likely to help out their preferred candidates in other elections. Thus, there is no real competition to make election administration better, which is presumably why states require elections for these offices in the first place.

Mismatch problems frequently occur in situations where there are nested elections, or where individual voters are asked to make choices about officials at a number of different levels of government. The reasons why such problems occur have been laid out above-EP elections, American big city local elections, and secretary of state elections all have similar characteristics. However, it is not necessarily the case that nested elections will develop mismatch problems. To the extent that national political parties can develop distinct local identities (or international ones, for the purposes of EP elections), there can be ordinary Downsian competition. Further, if mainstream independent local parties can be established, they can create competition. Also, if candidates can become well known enough, that too can introduce competition, something we see when prominent gubernatorial candidates are able to win elections in states where their party does not do well. Finally, to the extent preferences on national issues track closely preferences on whatever the body decides, the lack of competition becomes a less costly problem. ${ }^{229}$

However, nested elections will create mismatch problems if the political parties that contest local (or international) elections are national in scope, the individual candidates are not particularly well-known, and preferences about local (or international) issues do not track national preferences very closely. Where this occurs-and it occurs frequently-merely holding local, state or supra-national elections is not the same thing as getting public input on local, state or supra-national policies. Absent competition along these dimensions, there is little reason to believe that such elections produce representative results or retrospective accountability.

Finally, mismatch problems are not limited to nested elections. Mismatch problems can occur between entities at one level of government. Daryl Levinson and Rick Pildes have shown that the intention of the framers of the U.S. Constitution that Congress checks the power and ambition of the President does not occur during periods of one-party governance. ${ }^{230}$ One reason for this is how congressional elections operate. ${ }^{231} \mathrm{~A}$ member of Congress will not get any electoral benefit from checking the power of the President if the President is likely to define the popularity of that member's political party.

229. Even in this situation, these elections may have the problem of not providing much of a check on abuse by officials, as corrupt officials can continue in office by function of maintaining support from their major party and from voters who vote the party line.

230. See Daryl J. Levinson \& Richard H. Pildes, Separation of Parties, Not Powers, 119 Harv. L. Rev. 2311,2315 (2006).

231. See id. at $2323-24$. 
Limiting the power of the President from her own party will also often make it harder for a member of Congress to achieve specific policy goals or provide local benefits that help him or her electorally. ${ }^{232}$

Examining mismatch problems together provides a benefit, as they suggest a menu of options to respond to mismatch problems. The scholarship has identified three possible solutions for mismatch problems. First, my work on American urban elections and this Article suggest electoral engineering solutions. States could pass laws barring national parties from contesting local elections, or at least removing the limitations on developing distinct local identities, with the goal of developing locally-meaningful parties and party heuristics. ${ }^{233}$ The EU, as is suggested in Part III.B of this Article, could pass laws that require parties to get votes in multiple countries, forcing the development of pan-European parties and party heuristics.

Second, Gerken suggests an alternative, less intrusive response: the development of an alternative heuristic. For instance, she argues that private groups, with the aid of the national government, should develop a ranking system, a Democracy Index, that would rank state electoral systems along widely-agreed upon metrics, like time spent waiting to vote or lost ballots. ${ }^{234}$ Among other benefits, this would give voters a clear, easy-to-understand heuristic when they vote for secretaries of state. ${ }^{235}$ This would provide voters with the ability to achieve the ends behind having secretary of state elections.

Lastly, on the other side of the ledger, Levinson and Pildes suggest changing institutional arrangements. If Congress does not check the President during periods of one-party rule because majority party members have no incentive to do so, the minority party in Congress should be given certain powers-like the power to investigate-so there is a check on the President. ${ }^{236}$ Further, supermajority rules and increased judicial skepticism of laws passed during one-party governance might be justified to ensure a healthy check on presidential power. ${ }^{237}$ These institutional arrangements incorporate an understanding of the incentives of elected officials given how voters actually make voring decisions. Rather than seeking to make politics fit institutional goals, they seek to make institutions fit political reality. This is, in many ways, the opposite response to a similar type of problem.

It is not clear what type of response will be best in any given mismatch problem, whether it will be best to change institutions or types of political competition. Little is known about how any of these possible responses would do, as they are largely untried. However, it is clear that, to the extent

232. Id. at 2323-27; see also Daryl Levinson, Empire Building, 118 Harv. L. Rev. 915, 936-41 (2005).

233. See Schleicher, City Council Elections, supra note 31, at 468-73.

234. GERKEN, supra note 227 , at 5-6, 26-37.

235. Id. at 66-80.

236. Levinson \& Pildes, supra note 230 , at 2368-71.

237. See id. at $2372-75$. 
we care whether our constitutions work, we need to think about how elected institutions interact with political party competition and poorly informed voters.

The view of election law in this Article is somewhat different from the form it takes in most of the scholarship on the subject. Election law scholars have grown used to studying things like ballot access rules and questions of internal party governance in a variety of ways - to see whether these are ways for incumbent politicians to entrench themselves or for one political faction to gain advantage over another, how they affect specific political rights, or even to see what they say about broader questions about the meaning of representation in a democratic polity. ${ }^{238}$ These are, of course, important ways of looking at these policies, crucial to assessing the quality of these rules and how they should be reviewed by courts or independent bodies.

However, here the focus is on something different: how election rules provide information to a bored and disinterested populace. ${ }^{239}$ The work of scholars like Fiorina shows that the content of a nation's election laws (e.g. the availability of party heuristics on the ballot) is essential to the process of how voters develop preferences. ${ }^{240}$ When voters base their decisions on which policies will be enacted by the officials for whom they vote, even if only partially or imperfectly, it results in better democratic outcomes under virtually all possible theories of what democracy is supposed to accomplish. However, the ability of rationally under-informed voters to do this relies on the availability of clear, consistent, office-relevant heuristics and political markets will only sometimes and under some conditions provide them. The social value of such heuristics is higher than their cost. Rather than serving as a tool for deciding which type of representation voters should get, or as a weapon for incumbent politicians, election law in this view is a public good. ${ }^{241}$ It is up to the bodies that regulate elections to ensure that these public goods are provided and provided properly.

238. See generally Guy-Uriel E. Charles, Democracy and Distortion, 92 CoRnell L. Rev. 601, 604 (2007); Heather K. Gerken, A Third Way For the Voting Rights Act: Section 5 and the Opt-In Approach, 106 Colum. L. Rev. 708, 748-49 (2006).

239. Saying that election laws have a major effect on how voters form preferences is a very different thing from saying that election campaigns do. James Gardner has recently written an excellent book attacking the notion that much persuasion happens during campaigns, and noting that much political discourse (and legal thinking) that is built around the idea that campaigns are true deliberative debates is flawed. See James A. Gardner, What Are Campaigns For? The Role of Persuasion in Election LAW AND Poutics 1-7 (2009). However, this does not address whether the laws that structure politics give voters tools that allow them to develop informed opinions. For instance, election law rules are crucial to ensuring that parties are consistent in their ideological positions over time. Decisions like Duke v. Massey, 87 F.3d 1226 (11th Cir. 1996), in which the Republican Party was allowed to expel David Duke for ideological apostasy, give political parties greater control over their own ideological brand. Parties that are consistent ideologically over time allow voters to develop useful running tallies based on retrospective evaluations of how politicians behave while in office. The legal rule is hence relevant to the voting decision. However, none of this requires that anything happens during an election campaign.

240. See supra notes 161-163 and accompanying text.

241. A public good is traditionally defined as a good that is both non-rivalrous and non-excludable. In other words, the consumption of the good by one person does not bar consumption of the good by 
Looking at election laws as public goods allows us to see the difference between the investment we put in democratic governance and the demands our Constitution (and state constitutions and the EU's institutional structure) puts on voters. If our constitutional systems are to achieve their visions of self-governance, the public good of election law needs to be provided in a way that respects the limitations of the selves who are asked to do the governing. Otherwise, we will be left with legislatures and officials who win elections for reasons entirely unrelated to their performance and with constitutions that do not work. That is to say, we will be left with the problem of mismatch.

another person, and no one can be barred from using the good. Abraham Bell \& Gideon Parchomovsky, of Property and Antiproperty, $102 \mathrm{MICH}$. L. Rev. 1, 9 (2003). Public goods are underprovided by markers because the producers of the good do not capture the full benefits of consumption of the good. Id. at 9-11. Information is generally considered to be the purest of all public goods. Id. at 11. Relevant heuristics for a level of government are exactly the types of public goods that are underprovided by political markets-they are valuable to voters, but not necessarily in ways that translate into votes for the parties that would bear the cost of developing them. See id. at 14-17. 
